\title{
Kolonoskopi Hastalarında Bilinçli Sedasyon ve Analjeziye Nonopioid Bir Yaklaşım; Propofol - Ketamin (Ketofol)*
}

\author{
A Nonopioid Approach to Conscious Sedation and Analgesia in \\ Colonoscopy Patients; Propofol - Ketamine (Ketofol)*
}

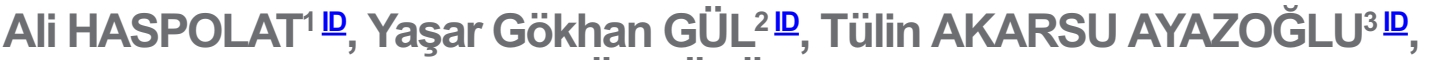 \\ Tuncer KOÇAK ${ }^{4} \underline{1}$, Ali Şefik KÖPRÜLÜ5 1 D
}

\author{
AH: 0000-0003-2787-5889 YGG: 0000-0001-9531-4317 TAA: 0000-0002-7840-0712 TK: 0000-0002-6428-8694 \\ AŞK: 0000-0003-1392-8855

\begin{abstract}
${ }^{1}$ Kolan International Hastanesi - Şişli MYO Anesteziyoloji Bölümü, İstanbul, Türkiye
${ }^{2}$ Medipol Mega Üniversite Hastanesi, Anesteziyoloji ve Reanimasyon Kliniği, İstanbul, Türkiye

${ }^{3}$ Istanbul Medeniyet Üniversitesi Tıp Fakültesi Anesteziyoloji ve Reanimasyon Kliniği, İstanbul, Türkiye

${ }^{4}$ Sağlık Bilimleri Üniversitesi Kartal Koşuyolu Yüksek İhtisas Eğitim Araştırma Hastanesi Anesteziyoloji ve Reanimasyon

Kliniği, İstanbul, Türkiye

${ }^{5}$ Yeni Yüzyıl Üniversitesi Tıp Fakültesi, Anesteziyoloji Reanimasyon Kliniği, İstanbul, Türkiye
\end{abstract}

\section{Özet}

Çalışmamızda tanısal kolonoskopide bilinçli sedasyonda uygulanan 1:3 Ketamin / Propofol (Grup-I) ve Petidin / Propofol (Grup-II) kombinasyonlarını; toplam ilaç dozu, indüksiyon, sedasyon-derlenme süreleri, hasta-endoskopist açısından işlem memnuniyeti, hemodinamik, solunumsal parametrelere etkileri ve saptanan diğer yan etkiler açısından karşılaştırdık.

ASA I-II 60 hasta çalışmaya katıldı. G-I'de indüksiyon süresi $2,15 \pm 0,38 \mathrm{dk}$., derlenme süresi $22,12 \pm 6,23 \mathrm{dk}$. olarak saptandı. Toplam $67,81 \pm 14,38 \mathrm{mg}$. propofol kullanıldı. G-II’de ise indüksiyon sü-

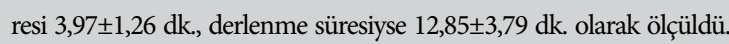
Propofol dozu 79,88 $\pm 17,59 \mathrm{mg}$. oldu. G/I-II arasinda toplam propofol dozu, indüksiyon-derlenme süreleri açısından istatistiksel anlamlı fark varken, kolonoskopi-sedasyon süresi açısından fark saptanmadı. OAB'da G-I’de grup içi karşılaştırmada hiçbir ölçümde istatistiksel anlamlı düşüş saptanmazken G-II'de 5. dakikadaki ölçüm işlem öncesine göre istatistiksel anlamlı azaldı. Gruplar arası karşlaştırma da ise herhangi bir fark saptanmadı. KAH ve SpO2'de ise her iki grupta da grup içi ve sonrasında yapılan gruplar arası karşlaştırmada istatistiksel anlamlı fark yoktu. G I’de kolonokopi sırasındaki VAS değerleri 1,36 $\pm 1,14$ iken G-II'de 2,13 $\pm 1,49$ olarak bulundu. Aradaki fark istatistiksel olarak anlamlı olmasına karşın her iki değerde ağrı sınııının altında kaldı. İşlem sırasında RSS'de G-I ve II arasında istatistiksel olarak anlamlı fark görülmesine karşın her iki grupta da çalışma öncesi hedeflenen sınırlar

(*) Danışmanlığını Doç. Dr. Tülin Akarsu Ayazoğlu'nun yaptığı Uzm. Dr. Ali Haspolat'a ait Tıpta Uzmanlık Tezi'nden üretilmiştir. 52. Ulusal Türkiye Anesteziyoloji Reanimasyon Kongresi 07-11 Kasım 2018 Antalya'da sözlü bildiri olarak sunulmuştur. 
(RSS 3-4) içinde kaldı. Derlenme odasındaki 5. dakika ölçümlerinde ise G-II'de RSS ve OAA/S belirgin olarak düşüktü ve istatistiksel fark anlamlıydı. AKŞ่de grup içi karşılaştırmalarda ve gruplar arası kolonoskopi öncesi değerlerde fark saptanmazken işlem sonrası KŞ değerleri arasındaki fark G-I'de istatistiksel olarak anlamlı artmış bulundu. Ancak değerler hiçbir hastada hiperglisemi sınırlarını geçmedi. Hiçbir hastanın kolonoskopisi sedasyon ilaçlarının yan etkileri nedeniyle yarıda bırakılmadı ve hastane yatışı gerekmedi. Yan etki olarak arada istatistiksel fark olmasa da bulantı, kusma G-II'de, genel halsizlik, baş ağrıs1-sersemlik G-I'de daha sıktı. Ancak uyanırken rüya görme-sayıklama gibi psikomimetik yan etkiler sadece G-I’de görüldü. Hasta-endoskopist memnuniyeti açısından G-I/II arasındaki fark istatistiksel olarak anlamlı değildi.

Sonuç olarak tanısal endoskopi hastalarında, hasta-hekim memnuniyetinin üst düzeyde olması, opioid kullanımı istenmeyen hastalarda ketaminin iyi bir alternatif olduğunu düşündürmektedir. Ancak psikomimetik etkileri engellemek amacılla ketamin dozunu azaltmanın mümkün olabileceğini, 3:1 yerine 10:1, 20:1 gibi seçeneklerin irdelenmesi gerektiğini düşünmekteyiz. Ancak düşen ketamin dozunun propofolun respiratuvar sisteme olan negatif etkilerini antagonize edemiyebileceği, respiratuvar komplikasyonların görülebileceği hatırlanmalıdır.

Anahtar Kelimeler: Kolonoskopi, Sedasyon, Propofol-Ketamin (Ketofol), Propofol-Petidin

\section{Gíriș}

Alt gastrointestinal sistem rahatsızlıklarının tanı ve tedavisinde kullanılan kolonoskopi son yıllarda en sık uygulanan endoskopik girişimlerden birisidir (1). Bu işlem düşük ağrı eşikli, anksiyetesi ve kolon duyarlılığ 1 yüksek, kolonda farklı anatomik varyasyonlar gösteren önemli yüzdesi yaşlı olan hastalar için hoş olmayan, rahatsızlık verici, kimi zaman da oldukça ağrılı bir uygulamadır. Yeteri kadar efektif giderilemeyen anksiyete ve ağrı, sempatik stimülasyon-katekolamin deşarjıyla sistemik vasküler direnç, kalp işi, miyokardın oksijen tüketiminde artışa ve tüm bunlar kardiyak dengeleri hassas olan hastalarda hemodinamik, respiratuvar dengeleri bozarak olumsuz yan etkilere neden olur (2). Ek olarak vasovagal reaksiyonlar da hiç azımsanmayacak oranda sıktır. Net sonuç morbidite ve mortalitede artıştır.

Kolonoskopide sedasyon uygulaması pratikte ülkeler arasında önemli farklılıklar içerir. Batı ülkelerinde neredeyse standart olarak tüm işlemlere uygulanırken çoğu Asya, Ortadoğu ve Güney Amerika ülkesinde tanısal işlemlerde kullanılmaz. Oysa Batı toplumlarında groups remained within the targeted limits (RSS 3-4) before the study. The 5th minute measurements in the recovery room, RSS and OAA / S were significantly lower in G-II and the statistical difference was significant. While there was no difference in intra-group comparisons and pre-colonoscopy values in BGL, the difference between post-treatment in BG values was in an increased statistically significant manner in G-I. However, the values did not exceed hyperglycemia limits in any patient. No patient's colonoscopy was discontinuation was required due to the side effects of sedation medications and no hospitalization was essential. Although there was no statistical difference as a side effect, nausea, vomiting was more common in G-II, whereas general weakness, headache-dizziness was seen in G-I. Yet, while waking up, psychomimetic side effects such as dreaming and singing were seen only in G-I. The difference between G-I / II in terms of patient-endoscopist satisfaction was not statistically significant.

In conclusion, high level of patient-physician satisfaction in diagnostic endoscopy patients suggests that ketamine is a good alternative in patients who do not want opioid use. However, we think that it may be possible to reduce ketamine dose in order to prevent psychomimetic effects. We propose options such as 10: 1, 20: 1 instead of 3: 1. However, it should be remembered that the decreased ketamine dose may not antagonize the negative effects of propofol on the respiratory system, and respiratory complications may be observed.

Key words: Colonoscopy, Sedation, Propofol-Ketamine (Ketofol), Propofol-Petidine

hastalar kadar hekimler de sedasyonla endoskopinin daha rahat tolere edildiğine inanırlar. Ülkemizde de kolonoskopiler giderek artan oranda sedasyon altında yapılmaktadır. Kolonoskopi günübirlik bir işlemdir. Günübirlik işlemlerde hasta sirkulasyonu hızlı olduğundan kullanılacak ilacın etkisi hızlı başlamalı, anestezi/analjezi derinliği kolayca titre edilebilmeli, ciddi yan etkilere neden olmamalı, sedasyon etkisinden kurtulma - derlenme çabuk olmalıdır. Bu özelliklere sahip olan tek bir ajan olmadığından genellikle fark$l_{1}$ ilaç kombinasyonları tercih edilmektedir. Pek çok farklı kombinasyon kullanılmasına karşın son 15 yılda midazolam-petidin en sık kullanılan "konvansiyonel" kabul edilen yöntemdir (3). Ancak sedasyon için benzodiazepin kullanımı sanıldığı kadar da masum değildir. Uygulama sırasında \%26-35 hastada klinik olarak önemli düzeyde solunum depresyonu / hipoksi saptanabileceği bildirilmiştir (4). Ek olarak yaşli, obez ve KOAH'lı hastalarda beligin kardiyak yetersizliğe yol açar $(4,5)$. Ayrıca gecikmiş uyanma, uzun süreli davranışsal değişiklikler ve kognitif fonksiyon bozuklukları hiç de nadir saptanmaz (5). 
Son yıllarda propofol, hızlı derlenme ve diğer farmakolojik özellikleri ile midazolamın yerini almaktadır (6). Ancak analjezik etkinliği olmaması nedeniyle ağrılı durumlarda tek başına kullanımında yüksek dozlara çıkılması solunum depresyonu gibi yan etkiler oluşturarak özellikle ameliyathane dışı ve anestezistin olmadığı koşullarda büyük sorunlara neden olur $(7,8)$. Sinerjik etki elde edebilmek, istenmeyen etkileri azaltmak amaciyla sıklıkla opioidlerle birlikte kullanımı önerilmektedir (9). Ancak bu ajanların da birlikte kullanımının ciddi yan etkilere neden olabileceği bildirilmiștir (10).

Ketamin sedatif, amnestik, hipnotik özelliklerinin yanı sıra güçlü merkezi etkili bir analjeziktir. Tek başına kullanıldığında sempatomimetik etkiyle kalp hızını ve arteryal tansiyonu solunum depresyonu yapmaksızın arttırır (11). Propofolle birlikte kullanımda yukarıdaki özellikleri sayesinde ketamin hem propofolün yan etkilerini antagonize eder hem de karışıma non opioid analjezik etkinlik ekler. Böylece her ikisi de tek başına kullanıldıklarında verilecek dozdan daha düşük dozda kullanılabilir ve yan etkilerden kaçınmak mümkün olabilir. Aynı enjektörde kötü etkileşim, çökelme vs olmadan iyi bir karışım meydana gelir (Ketofol) ve uygulama kolaylığı da sağlar (12).

Biz de bu çalışmamızda bilinçli sedasyonda yaygın kullanılan propofolün konvansiyonel tekniğin ve postoperatif analjezinin en sık kullanılan ajanı petidinle kombinasyonunun, nonopioid bir yaklaşım için umut veren propofol/ ketamin kombinasyonuyla; toplam ilaç dozları, indüksiyon, sedasyon ve derlenme süreleri, hasta-endoskopist açısından işlem kalitesi, hastaların hemodinamik ve solunumsal parametrelere etkileri ve saptanan diğer yan etkiler açısından karşılaştırmayı hedefledik.

\section{MATERYAL ve METOD}

Etik kurulunun onamını (Tarih/Sayı: 08.08.2011 - An006/2011) takiben hastanemiz Endoskopi Ünitesi'nde değişik nedenlerle tanısal kolonoskopi uygulanması planlanan ve isim belli olmadan tıbbi verilerinin kullanılabileceğine dair imzalı onamları olan ASA I-II 60 erişkin hasta prospektif, randomize, çift kör çalışmaya dahil edildi. Aşağıdaki kriterlerden herhangi birisine sahip olan hastalar çalışma grubuna alınmadı;

- III ve üzeri ASA değeri,

- 18 yaşından küçük, 80 yaşından büyük olanlar,

- VKİ $>35 \mathrm{~kg} / \mathrm{m}^{2}$ (ileri derecede obesite),

- Mental retardasyon, demans, dil bilmeme vb. gerekçelerle yeterli iletişim kurulamayanlar,
- Hava yolu güçlüğü olması beklenenler,

- Anamnezinde uyku apnesi olanlar,

- Nöropsikiyatrik bozukluğu olan ve/veya psikotropik ilaç kullananlar,

- Narkotik, benzodiazepin ya da benzeri uygunsuz ilaç, alkol ve keyif verici madde kullananlar,

- Devamlı oksijen gerektirecek kadar ağır restriktif/obstruktif akciğer hastalığı olanlar,

- İleri derecede kalp, böbrek ve/veya karaciğer yetmezliği olanlar,

- İnsulin bağımlı diyabeti olanlar,

- Hamile ya da bebeğini anne sütüyle besleyen kadınlar,

- Çoklu batın girişimi geçiren ya da postoperatif kontrol hastaları,

- Kullanılacak ilaçlardan herhangi birine ya da yumurta, soya alerjisi olanlar,

- Yetersiz barsak temizliği nedeniyle endoskopisi yarıda kesilenler.

2 gün süreyle sıvı diyet verilmiş, işlem öncesi 4-6 saat süreyle oral alımı olmayan, XM-Diet Solusyon ${ }^{\oplus}$, Bekunis draje $^{\oplus}$ ve BT Enema lavman $\odot$ ile barsak hazırlığı yapılmış (13) olan tüm hastalar işlem öncesi anesteziyoloji değerlendirmesi sırasında çalışma ve Görsel Ağrı Skalası (VAS) hakkında bilgilendirildi $(0=$ hiç ağrı yok, $10=$ en şiddetli ağrı) (14), katılım konusunda yazılı onamları alındı. Çalışmaya kabul kriterlerine uyan hastalar kapalı zarf çekme yöntemiyle rastlantısal olarak iki gruba bölündü. Grup I'e ( G I, n= 30) aynı enjektör içine çekilmiş ketamin hidroklorür ile propofol (15) (karışım oranı 1:3 - $50 \mathrm{mg}$. ketamin, $150 \mathrm{mg}$. propofol, $34 \mathrm{ml} . \% 0.9 \mathrm{NaCl}$ toplam $50 \mathrm{ml}$.) uygulanırken Grup II'de (G II, n= 30) aynı enjektör içinde petidin-propofol karışımı (karışım oranı 1:3 - $50 \mathrm{mg}$. petidin $\mathrm{HCl}, 150 \mathrm{mg}$. propofol, $34 \mathrm{ml}$. \% $0.9 \mathrm{NaCl}$ toplam 50 $\mathrm{ml}$.) tercih edildi (16). Uygulama hastanın kilosu ve bolus / perfüzyon dozlarının girildiği otomatik enjektör pompası (B. Braun Melsungen ${ }^{\circledR}$, Germany) ile yapıldı.

İşlem sırasında hastaların bilinçli sedasyon (orta derecede sedasyon - Ramsey Sedasyon Skalası 3-4) düzeyinde tutulması hedeflendi (17). G I de 1:3 ketamin/propofol karışımından (ketofol) ketamin 0,2 mg/kg., propofol 0,6 $\mathrm{mg} / \mathrm{kg}$. bolus, ketamin $10 \mu \mathrm{gr} / \mathrm{kg} / \mathrm{dk}$, propofol $30 \mu \mathrm{gr} / \mathrm{kg} /$ $\mathrm{dk}$ perfüzyon; G II de ise $1: 3$ petidin/propofol karışımından $0,2 \mathrm{mg} / \mathrm{kg}$ petidin, $0,6 \mathrm{mg} / \mathrm{kg}$ propofol bolus, petidin $10 \mu \mathrm{gr} / \mathrm{kg} / \mathrm{dk}$, propofol $30 \mu \mathrm{gr} / \mathrm{kg} / \mathrm{dk}$ perfüzyon uygulan$\mathrm{d}_{1}$ ( $1 \mathrm{ml}$. = $1 \mathrm{mg}$ ketamin "G I" veya petidin "G II", 3 mg propofol / 65 kiloluk bir hasta için $13 \mathrm{cc}$ bolus, $39 \mathrm{cc}$ / 
Tablo 1. Demografik Özelliklerin Gruplara Göre Dağılımı

\begin{tabular}{|l|l|c|c|c|c|c|}
\hline \multicolumn{2}{|c|}{} & \multicolumn{2}{c|}{$\begin{array}{c}\text { Grup I } \\
\text { (Propofol + Ketamin) }\end{array}$} & \multicolumn{2}{c|}{$\begin{array}{c}\text { Grup II } \\
\text { (Propofol + Petidin) }\end{array}$} & \\
\hline \multirow{2}{*}{ ASA } & I & Sayı & $\%$ & Sayı & $\%$ & \\
\cline { 2 - 7 } & II & 15 & 50,00 & 18 & 60,00 & \\
\hline \multirow{2}{*}{ Cinsiyet } & Kadın & 15 & 50,00 & 12 & 40,00 & \\
\cline { 2 - 7 } & Erkek & 20 & 66,66 & 15 & 50,00 & \\
\hline & 10 & 33,33 & 15 & 50,00 & \\
\hline Yaş (yıl) & Ortalama & SD & Ortalama & SD & P değeri \\
\hline Vucüt Ağırlığı (kg) & 66,2 & 14,9 & 62,7 & 12,6 & 0,314 \\
\hline Boy (cm) & 69,8 & 13,1 & 74,6 & 11,7 & 0,131 \\
\hline $\begin{array}{l}\text { Vücut Kitle Indeksi } \\
\text { (kg/m }{ }^{2} \text { ) }\end{array}$ & 163,2 & 11,8 & 164,4 & 12,3 & 0,164 \\
\hline
\end{tabular}

(*) $p<0,05$ istatistiksel olarak anlamlı fark $\left(^{* *}\right) p<0,001$ istatistiksel olarak ileri derecede anlamlı fark

saat perfüzyon). Klinik olarak hedeflenen düzey üzerinde sedasyon skoru saptandığında perfüzyon dozu \%10 azaltıldı. Hedeflenen düzeyin tutturulamadığ 1 ya da işlem sırasında ağrı hissedilen (VAS $>3$ ) olgularda ise perfüzyon dozu \%10 arttırıldı. Yetersiz kalması durumunda indüksiyon dozunun \%50'si IV bolus tekrarland. Sedasyonun ve işlem sonrası takibin aynı anestezi hekimince ve tüm kolonoskopik tetkiklerin aynı deneyimli endoskopistce yapılmasına özen gösterildi. Uygulamayı yapan endoskopistin ve işlem sırasında/sonrasında derlenme odasında hastayı takip eden tüm anesteziyoloji ekibinin hastanın hangi gruptan olduğunu bilmemesine özen gösterildi.

Hastalar yaş, cins, vücut ağırlı̆̆ı, boy, vücut kitle indeksi ve endoskopi endikasyonlarının kayıt edilmesinden sonra işlemin uygulanacağı salona alındı. El üzeri ya da antecubital venlerden $20 \mathrm{G}$ damar yolu açıldı. Kan şekeri için örnek alındı ve $10 \mathrm{ml} / \mathrm{kg} / \mathrm{saat} \% 0.9 \mathrm{NaCl}$ sıvı perfüzyonu başlandı. 5 elektrodlu iki kanal EKG, noninvazif arteryal kan basinc1, oksijen saturasyonu (SpO2) ile monitörize edildi. Tüm hastalara sedasyon süresince nasal kanülle $2 \mathrm{lt} / \mathrm{dk}$ oksijen uygulandı. Hastanın grubuna göre IV bolus ve perfüzyon olarak ilaçlarının uygulanmasını takiben RSS düzeyi ancak 3-4 olduğunda kolonoskopi uygulamasının başlanmasına izin verildi. Bolus dozun yapılmasindan hedeflenen sedasyon düzeyine ulaşıldığı süre "indüksiyon süresi” olarak kabul edildi. İşlem öncesi ve işlemin 1.,5., 10., 15., 20., 25., 30. dakikalarında hemodinamik parametreler olan kalp atım hızı (KAH - vuru/dk), ortalama arteryal kan basinc1 (OAB - mmHg), oksijen saturasyonu (SpO2 - \%) kayıt edildi. Her hastaya kolonoskopi süresince ağrı duyduğunda bilgi vermesi ve VAS’a göre ağrı puanlaması yapması hatırlatıldı.

Kolonoskopi bitimini takiben perfüzyon kesildi. İlaçların bolus verildiği süreden perfüzyonun kesildiği ana dek geçen zaman "sedasyon süresi" olarak kabul edildi. Hastalar monitörize halde derlenme odasına alındi. Hastanın stabilizasyonunu takiben derlenme üniresindeki 5. dakikada VAS değeri, Ramsey Sedasyon Skoru (18), Gözlemcinin Sedasyon ve Uyandırabilirlik Skalası (OAAS) (19), kolonoskopi sonrası kan şekeri ölçülerek not edildi. Taburculuğa müsaade edilebilecek düzeye gelmesi Modifiye Aldrete Skoru (MAS) ile değerlendirildi (20). Sedasyon bitiminden MAS $\geq 9$ olmasına dek geçen süre "derlenme süresi" olarak tanımland. MAS $\geq 9$ olduğunda taburcu işlemi refakatçi eşliğinde yapıldı. İşlemle ilgili süreler (sedayon, kolonoskopi, indüksiyon, derlenme) propofol, ketamin ve petidin dozları, uygulamayı yapan endoskopistin memnuniyet puanı (1. Kötü, 2. Orta, 3. İyi) not edildi. İşlem sırasındaki ve sonrasındaki yan etkiler ayrıca kayıt altına alındı. Arteryal basıncın basal değerlere göre \%20 artışı hipertansiyon, \%20 azalması hipotansiyon, kalp atım hızının 50 vuru/dk'nın altına inmesi bradikardi, 120 vuru/dk’nın üzerine çıkması taşikardi, ok- 
Tablo 2. Gruplar Arası Sürelerin ve Propofol Dozlarının Karşılaştırıması

\begin{tabular}{|l|c|c|c|c|c|}
\hline & \multicolumn{2}{|c|}{ Grup I } & \multicolumn{2}{c|}{ Grup II } & \\
& (Propofol + Ketamin) & (Propofol + Petidin) & \\
\hline & Ortalama & SD & Ortalama & SD & P Değeri \\
\hline Kolonoskopi Süresi (dk) & 13,26 & 5,21 & 14,01 & 6,12 & 0,566 \\
\hline İndüksiyon Süresi & 2,15 & 0,38 & 3,97 & 1,26 & $0,031^{*}$ \\
\hline Sedasyon Süresi & 15,98 & 6,46 & 16,88 & 5,87 & 0,323 \\
\hline Derlenme Süresi & 22,12 & 6,23 & 12,85 & 3,79 & $0,000^{* *}$ \\
\hline Propofol dozu (toplam) & 67,81 & 14,38 & 79,88 & 17,59 & $0,009^{*}$ \\
\hline Ketamin (mg.) & 22,61 & 4,79 & - & - & \\
\hline Petidin (mg.) & - & - & 26,63 & 5,86 & \\
\hline
\end{tabular}

$(*) p<0,05$ istatistiksel olarak anlamlı fark $\left(^{* *}\right) p<0,001$ istatistiksel olarak ileri derecede anlamlı fark

sijen doygunluğunun 20 sn'den daha uzun süre \%90'nın altında olması hipoksi, \%90-94 aralığında olması ise hipoksi eğilimi olarak kabul edildi. Görsel olarak hastanın 10 sn süreyle nefes alma çabasında bulunmaması apne olarak değerlendirildi. Ayrıca bulantı, kusma, baş ağrısı, sersemlik, genel halsizlik, uyanırken rüya-kabus görme, sayıklama özellikle sorgulanarak kayıt altına alındı. Hipotansiyona öncelikli olarak $20 \mathrm{ml} / \mathrm{kg} / \mathrm{saat} \% 0.9 \mathrm{NaCl}$ solusyonuyla, yanıt vermezse $1 \mathrm{~g} / \mathrm{kg}$ efedrin IV yavaş bolus enjeksiyonla, bradikardiye ise atropin $0,01 \mathrm{mg} / \mathrm{kg}$ IV yavaş bolus enjeksiyonla müdahale edildi. Hipertansiyon ve/veya taşikardi saptandığında ise, ağrı, anksiyete nedenli olduğu düşünülen hastalarda başlangıç dozunun \%50'si kadar kullanılan sedasyon ajanı tekrarlandi. Yanıtsiz kalan hastalarda IV beta bloker $(100 \mu \mathrm{gr} / \mathrm{kg}$ esmolol IV yavaş bolus enjeksiyon) kullanılması planlandı. Bulan$\mathrm{t}$, kusmaya ise $4 \mathrm{mg}$ ondansetron IV ile müdahale edildi. Bulantı kusması devam eden hastalara aynı doz ikinci kez yapıldı.

İşlem üzerinden 24 saat geçtikten sonra hastalarla telefonla iletişim kurularak endoskopistin değerlendirme yaptığ 1 skala benzeri skalayı kullanılarak (1. Kötü, 2. Orta, 3. İyi) hastanın kolonoskopi işlemini değerlendirmesi istendi.

Çalışmanın istatistiksel değerlendirmesinde SPSS 15.0 for windows programı kullanıldı. Tanımlayıcı istatikler ortalama ve standart sapma olarak verildi. Verilerin normal dağılıma uygunlukları "Kolmogorov-Smirnov dağılım testi", nitel verilerin karşılaştırılmasında ise "Ki Kare" ve
"Fisher Exact test" kullanıldı. Niceliksel verilerin iki grup arasındaki karşılaştırılmasında normal dağılım gösteren parametreler için "Bağımsız Örnekler T Testi (independent samples $t$ test)" ve normal dağılım göstermeyenler içinse "Mann Whitney U test" kullanıldı. Parametrelerin aynı grup içindeki karşılaştırmalarında ise "Wilcoxon İşaret Testi” tercih edildi.

\section{BULGULAR}

Çalışma yaşları 18 ile 80 arasında değişmekte olan $35^{\prime} \mathrm{i}$ kadın (\%58,3), 25’i erkek (41,7) toplam 60 hasta dahil edildi. Olguların ortalama yaşı $64,4 \pm 13,8$ di. Ortalama kilo 72,2 $\pm 12,5 \mathrm{~kg}$. (minimum 38, maksimum 101 $\mathrm{kg}$.), boy $163,84 \pm \mathrm{cm}$. (151-189 cm.), vucüt kitle indeksi $26,87 \pm 1,73 \mathrm{~kg} / \mathrm{m}^{2}(19,92-33,91 \mathrm{~kg} / \mathrm{m} 2)$ olarak saptand. Hastaların \%55 i ASA I (33 hasta), \%45'i ise ASA II (27 hasta) idi. G I ve II arasında istatistiksel değerlendirme de demografik veriler açısından herhangi bir fark görülmedi. Hastaların gruplara göre demografik bulguları tablo 1'de özetlenmiştir.

G I'deki hastalarda indüksiyon süresi $2,15 \pm 0,38 \mathrm{dk}$., kolonoskopi süresi $13,26 \pm 5,21 \mathrm{dk}$., sedasyon süresi $15,98 \pm 6,46 \mathrm{dk}$. ve derlenme süresi $22,12 \pm 6,23 \mathrm{dk}$. olarak saptand. Bu grupta toplam 22,61 $\pm 4,79 \mathrm{mg}$. ketamin, $67,81 \pm 14,38 \mathrm{mg}$. propofol kullanıldı. G II'de ise indüksi-

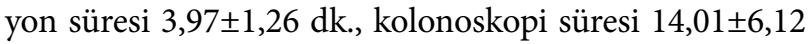
$\mathrm{dk}$., sedasyon süresi $16,88 \pm 5,87 \mathrm{dk}$. ve derlenme süresi ise 
Tablo 3. Ortalama Arteryal Basınç Değerleri ( $\mathrm{mmHg}$.)

\begin{tabular}{|c|c|c|c|c|c|}
\hline & \multicolumn{2}{|c|}{$\begin{array}{c}\text { Grup I } \\
\text { (Propofol + } \\
\text { Ketamin) }\end{array}$} & \multicolumn{2}{|c|}{$\begin{array}{c}\text { Grup II } \\
\text { (Propofol + Petidin) }\end{array}$} & \multirow[t]{2}{*}{ P Değer } \\
\hline & Ortalama & SD & Ortalama & SD & \\
\hline $\begin{array}{l}\text { İşlem } \\
\text { öncesi }\end{array}$ & 88,17 & 17,64 & 88,01 & 18,19 & 0,667 \\
\hline $1 \mathrm{dk}$. & 80,34 & 15,76 & 81,23 & 15,36 & 0,850 \\
\hline 5 dk. & 79,51 & 11,59 & 75,56 & 14,84 & 0,954 \\
\hline $10 \mathrm{dk}$. & 80,68 & 13,19 & 78,91 & 12,21 & 0,962 \\
\hline $15 \mathrm{dk}$. & 82,76 & 11,73 & 80,36 & 12,49 & 0,953 \\
\hline $20 \mathrm{dk}$. & 84,49 & 12,62 & 81,47 & 13,87 & 0,941 \\
\hline $25 \mathrm{dk}$. & 85,12 & 13,09 & 82,82 & 13,56 & 0,951 \\
\hline 30 dk. & 85,36 & 14,13 & 85,74 & 13,79 & 0,902 \\
\hline
\end{tabular}

(*) $p<0,05$ istatistiksel olarak anlamlı fark $\left(^{* *}\right) p<0,001$ istatistiksel olarak ileri derecede anlamlı fark

$12,85 \pm 3,79$ dk. olarak ölçüldü. Petidin dozu 26,63 $\pm 5,86$ $\mathrm{mg}$, propofol dozu ise $79,88 \pm 17,59 \mathrm{mg}$. oldu. G I ve II arasında indüksiyon ve derlenme süreleri açısından istatistiksel anlamlı fark varken $(\mathrm{p}<0,05)$, kolonoskopi ve sedasyon süresi açısından istatistiksel anlamlı fark saptanamadı ( $\mathrm{p}>0,05)$. Toplam propofol dozu açısından da gruplar arasında istatistiksel anlamlı fark görüldü $(\mathrm{p}<0,05)$. Tüm bulgular tablo 2'de gösterilmiştir.

Ortalama arter basıncı G I'de; işlem öncesi $88,17 \pm$ 17,64 mmHg., 1. dakikada $80,34 \pm 15,76 \mathrm{mmHg}$., 5 . dakikada 79,51 $\pm 11,59 \mathrm{mmHg}$., 10 . dakikada $80,68 \pm 13,19$ mmHg., 15. dakikada 82,76 $\pm 11,73$ mmHg., 20. daki-

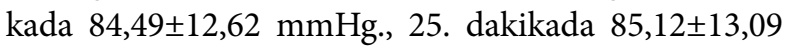
mmHg., 30. dakikada 85,36 $\pm 14,13 \mathrm{mmHg}$. olarak ölçüldü. G II'de ise değerler; işlem öncesi $88,01 \pm 18,19$ mmHg., 1. dakikada $81,23 \pm 15,36$ mmHg., 5. dakikada $75,56 \pm 14,84$ mmHg., 10 . dakikada $78,91 \pm 12,21$ mmHg., 15. dakikada 80,36 $\pm 12,49$ mmHg., 20. dakikada $81,47 \pm 13,87$ mmHg., 25. dakikada $82,82 \pm 13,56$ mmHg., 30. dakikada $85,74 \pm 13,79 \mathrm{mmHg}$. olarak bulundu. G I'de grup içi karşılaştırmada hiçbir ölçümde istatistiksel anlamlı düşüş saptanmazken G II'de 5. dakikadaki ölçüm işlem öncesine göre istatistiksel anlamlı azalmıştı $(\mathrm{p}<0,05)$. Gruplar arası karşılaştırmada ise istatistiksel anlamlı herhangi bir fark saptanmadı. Çalışma süresince G I'de sadece 1 hastada (\%3.33) başlangıç değerine oranla hipotansiyon gözlenirken G II'de 3 hastada aynı bulgu saptandı. G I'deki 1 hasta ve G II'deki 2 hasta taktil uyaran ve ek sıvı perfüzyonuyla kısa sürede toparlerken G II'deki diğer 1 hasta bu uygulamalara yanıtsız kalarak efedrin yapılmasını gerektirdi. Ancak o vaka da tek doz efedrin uygulamasına kısa sürede olumlu yanıt verdi ve dozun tekrarlanmasina gerek duyulmadan kolonoskopi komplikasyonsuz tamamlandı. Çalışma süresince G I'de hipertansiyon gelişen vaka olmamasına karşın G II'de ağrı duyduğunu (VAS=6) belirten bir hastada hipertansiyon saptand. Propofol/petidin karışımından indüksiyon dozunun yarısı kadar bolus yapılmasıyla beta bloker kullanmaksizın OAB normal sinırlara indi. Hastaların OAB değerleri tablo 3 'te özetlenmiştir.

Çalışma grubundaki hastalarımızın kalp atım hız-

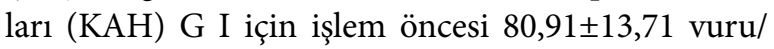
dk., 1. dakikada 78,81 $\pm 13,79$ vuru/dk., 5. dakikada $76,67 \pm 15,31$ vuru/dk., 10. dakikada 78,37 $\pm 14,01$ vuru/ dk., 15. dakikada 78,93 $\pm 13,12$ vuru/dk., 20. dakikada $80,71 \pm 13,91$ vuru/dk., 25 . dakikada $81,57 \pm 13,89$ vuru/ dk., 30. dakikada ise $81,89 \pm 13,35$ vuru/dk. olarak kayıt altına alındı. Grup II'de ise bu değerler işlem öncesi $83,13 \pm 14,28$ vuru/dk., 1 . dakikada $79,83 \pm 12,69$ vuru/ dk., 5. dakikada 79,33 $\pm 13,21$ vuru/dk., 10. dakikada $79,61 \pm 13,01$ vuru/dk., 15 . dakikada $80,13 \pm 12,51$ vuru/ dk., 20. dakikada 79,83 $\pm 12,78$ vuru/dk., 25. dakikada $79,12 \pm 13,15$ vuru/dk., 30. dakikada ise $76,69 \pm 15,05$ 
Tablo 4. Kalp Atım Hızı Değerleri (vuru/dk)

\begin{tabular}{|c|c|c|c|c|c|}
\hline & \multicolumn{2}{|c|}{$\begin{array}{c}\text { Grup I } \\
\text { (Propofol + } \\
\text { Ketamin) }\end{array}$} & \multicolumn{2}{|c|}{$\begin{array}{c}\text { Grup II } \\
\text { (Propofol + Petidin) }\end{array}$} & \multirow[t]{2}{*}{ P Değeri } \\
\hline & Ortalama & SD & Ortalama & SD & \\
\hline $\begin{array}{l}\text { İşlem } \\
\text { öncesi }\end{array}$ & 80,91 & 13,71 & 83,13 & 14,28 & 0,539 \\
\hline 1 dk. & 78,81 & 13,79 & 79,83 & 12,69 & 0,764 \\
\hline 5 dk. & 76,67 & 15,31 & 79,33 & 13,21 & 0,473 \\
\hline $10 \mathrm{dk}$. & 78,37 & 14,01 & 79,61 & 13,01 & 0,725 \\
\hline $15 \mathrm{dk}$. & 78,93 & 13,12 & 80,13 & 12,51 & 0,718 \\
\hline $20 \mathrm{dk}$. & 80,71 & 13,91 & 79,83 & 12,78 & 0,803 \\
\hline $25 \mathrm{dk}$ & 81,57 & 13,89 & 79,12 & 13,15 & 0,508 \\
\hline 30 dk. & 81,89 & 13,35 & 76,69 & 15,05 & 0,246 \\
\hline
\end{tabular}

$\left.{ }^{*}\right) p<0,05$ istatistiksel olarak anlamlı fark $\left(^{* *}\right) p<0,001$ istatistiksel olarak ileri derecede anlamlı fark

vuru/dk. olarak ölçüldü. Her iki grupta da grup içi ve sonrasında yapılan gruplar arası karşılaştırmada istatistiksel anlamlı fark yoktu. Çalışmaya katılan hastalardan G I de 1, G II'de ise 2 hastada bradikardi saptand.. G I deki ve G II'deki l'er hasta taktil uyaranla spontan düzelirken G II'deki 1 hasta taktil uyarana yanıtsız kaldı. Ancak aynı hastada eş zamanlı olarak sıvıya yanıtsız hipotansiyon geliştiğinden uygulanan efedrine arteryal tansiyonun yanısıra kalp atım hızı da olumlu yanıt verdi ve kolonoskopi komplikasyonsuz tamamlandı. Aynı şekilde G I'de hiçbir hastada taşikardi gelişmezken G II'de ağrı duyup hipertansiyon gelişen 1 hastada taşikardi saptandı. İndüksiyon dozunun $1 / 2$ 'sinin tekrarlanmasiyla beta blokersiz kontrol altına alındı.

Oksijen saturasyon değerleri (\%) sırasıyla; G I için işlem öncesi $99,27 \pm 0,83,1$. dakikada $97,07 \pm 1,39,5$. dakikada $95,27 \pm 2,79,10$. dakikada $98,37 \pm 1,13,15$. dakikada $99,01 \pm 0,83,20$. dakikada $99,53 \pm 0,82,25$. dakikada $99,63 \pm 0,79$ ve 30 . dakikada ise $99,78 \pm 0,73$ oldu. G II'de ise sirasıyla işlem öncesi $99,47 \pm 0,63,1$. dakikada $97,27 \pm 1,12$, 5. dakikada $95,33 \pm 2,23,10$. dakikada $97,71 \pm 1,34,15$. dakikada $98,87 \pm 0,91,20$. dakikada $99,17 \pm 0,61,25$. dakikada $99,24 \pm 0,59$, 30. dakikada 99,41 $\pm 0,51$ olarak saptand1. Her iki grupta da işlem öncesine oranla grup içi ve aynı dönemlerde gruplar arası istatistiksel olarak anlamlı fark görülmedi. Ancak her iki grupta da $\mathrm{SpO} 2$ 5. dakikada da en düşük değerlerine geriledi. G I'de hiçbir hastada hipoksi eğilimi saptanmazken G II'de sadece 2 hastada kısa süreli hipoksi eğilimi $(2 / 30$ - \%6,66) görüldü. Bu hastalarda da taktil uyaran ve nasal oksijenin 2 lt/dk.'dan 4 lt/dk.'ya arttırılmasıyla sorun çözümlendi. Tüm çalışma süresince hiçbir hastada hipoksi ve/veya apne gelişmedi ve solunumun maske-kese ile asiste edilmesi gereksinimi doğmadı.

G I'de hastaların kolonokopi sırasındaki VAS değerleri 1,36 $\pm 1,14$ iken G II'de bu değer 2,13 $\pm 1,49$ olarak saptand 1 . Aradaki fark istatistiksel olarak anlaml $(\mathrm{p}=0,041 / \mathrm{p}<0,05)$ olmasına karşın her iki değerde ağrı sınırının altında kal$\mathrm{d}_{1}(\mathrm{VAS}<4)$. Derlenme ünitesinde 5. dakikada VAS G I de $1,03 \pm 0,83$ olarak ölçümlenirken G II'de $1,46 \pm 0,85$ oldu. Aradaki fark istatistiksel olarak anlamlı değildi ( $\mathrm{p}=0.056 /$ $\mathrm{p}>0,05)$. İşlem sırasında G I'de 1 hastada ağrı saptanırken (VAS=4), G II'de ise 6 hasta ağrı tarifledi (5 hasta VAS=4, 1 hasta VAS=6). G I'deki hasta dozun \%10 arttırılmasından fayda gördü. G II'de ise 4 hasta doz arttırımından faydalanırken 2 hastada indüksiyon dozunun \%50'si bolus yapılması gereksinimi oldu. Derlenme ünitesinde ise G I'deki hiçbir hastada ağrı yakınması olmazken G II'de işlem sırasında ciddi ağrı yakınması duyan hastanın ağrısı azalmakla birlikte devam etti (VAS=4) ancak hastanın da isteği üzerine ek bir ilaç yapılmadı.

Kolonoskopi sırasinda RSS G I'de 4,43 $\pm 1,87$, G II'de ise $3,28 \pm 1,51$ olarak saptand 1 . Aralarında istatistiksel olarak 
Tablo 5. Oksijen Saturasyon Değerleri $\left(\mathrm{SpO}_{2}-\%\right)$

\begin{tabular}{|l|c|c|c|c|c|}
\hline & \multicolumn{2}{|c|}{$\begin{array}{c}\text { Grup I } \\
\text { (Propofol + } \\
\text { Ketamin) }\end{array}$} & \multicolumn{2}{c|}{$\begin{array}{c}\text { Grup II } \\
\text { (Propofol + Petidin) }\end{array}$} & P Değeri \\
\cline { 1 - 3 } & Ortalama & SD & Ortalama & SD & \\
\hline $\begin{array}{l}\text { İşlem } \\
\text { öncesi }\end{array}$ & 99,27 & 0,83 & 99,47 & 0,63 & 0,401 \\
\hline 1 dk. & 97,07 & 1,39 & 97,27 & 1,12 & 0,654 \\
\hline 5 dk. & 95,27 & 2,79 & 95,33 & 2,23 & 0,387 \\
\hline 10 dk. & 98,37 & 1,13 & 97,71 & 1,34 & 0,140 \\
\hline 15 dk. & 99,01 & 0,83 & 98,87 & 0,91 & 0,366 \\
\hline 20 dk. & 99,53 & 0,82 & 99,17 & 0,61 & 0,188 \\
\hline 25 dk. & 99,63 & 0,79 & 99,24 & 0,59 & 0,389 \\
\hline 30 dk. & 99,78 & 0,73 & 99,41 & 0,51 & 0,351 \\
\hline
\end{tabular}

$\left.{ }^{*}\right) p<0,05$ istatistiksel olarak anlamlı fark $\left(^{* \star}\right) p<0,001$ istatistiksel olarak ileri derecede anlamlı fark

anlamlı fark $(\mathrm{p}=0,043 / \mathrm{p}<0,05)$ görülmesine karşın her iki değerde çalışma öncesi hedeflenen sınırlar içinde kaldı. G I'de RSS'nin derinleşme eğilimiyle 9 hastada 1 kez, 2 hastada ise $2 \mathrm{kez}$ doz azaltımı yapıldı. G I'de sadece 1 kez doz arttırımına gidilirken G II'de sedasyon skorunu hedeflenen düzeyde tutmak ve analjeziyi sağlamak amacıyla $13 \mathrm{kez}$ doz arttırıldı. Derlenme odasın-

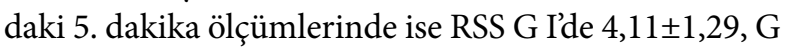
II'de 2,87 $\pm 1,09$ olarak saptandı. İstatistiki fark ileri derecede anlamliyd $1(\mathrm{p}=0,000 / \mathrm{p}<0,001)$. G I'de sedasyon kesilmiş olmasına karşın 14 hasta hedeflenen RSS değerinin üzerindeydi $(\% 46,66)$. G II'de ise sadece 3 hasta (\%10) aynı klinik tablodaydı. Aynı dönemde OAA/S G I'de $3,33 \pm 0,94$, G II'de 4,46 $\pm 1,03$ saptandı. Fark yine istatistiksel olarak anlamlıyd $1(\mathrm{p}=0,041 / \mathrm{p}<0,05)$. Aynı şekilde G I'deki hastaların 7'si $(\% 23,33)$ adı normal tonda söylenince yanıt verirken G II'de 18 hasta (\%60) aynı klinik skoru aldı.

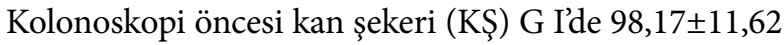
$\mathrm{mg} / \mathrm{dL}, \mathrm{G}$ II'de ise $95,87 \pm 11,94 \mathrm{mg} / \mathrm{dL}$. olarak ölçümlen-

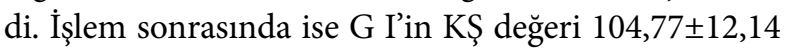

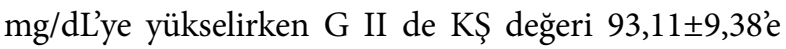
düştü. Grup içi karşılaştırmalarda ve gruplar arası kolonoskopi öncesi değerlerde istatistiksel anlamlı fark saptanmazken işlem sonrası KŞ değerleri arasındaki fark istatistiksel olarak anlamlı bulundu $(\mathrm{p}<0.05)$. Ancak değerler hiçbir hastada hiperglisemi sınırlarını geçme- di. Gruplar arası VAS, RSS, OAA/S ve kan şekeri sonuçlarının karşılaştırılması tablo 6 'da, hastaların derlenmenin 5. dakikasındaki skorlara göre dağılımı tablo 7'de özetlenmiştir.

Çalışma sırasında yukarıdaki bulgulara ek yan etki olarak bulantı (G I - 1 kişi / \%3,33, G II- 4 kişi / \%13,33), kusma (G I - 1 kişi / \%3,33, G II - 2 kişi / \%6,66), genel halsizlik (G I - 3 kişi / \%10, G II - 2 kişi / \%6,66), baş ağrısı-sersemlik (G I - 3 kişi / \%10, G II - 1 kişi / \%3,33), uyanırken rüya görme-sayıklama (G I - 3 kişi / \%10, G II - 0 kişi / \%0) saptand. Son semptom psikomimetik yan etki olarak kabul edildi. Hiçbir hastanın kolonoskopisi sedasyon ilaçlarının yan etkileri nedeniyle yarıda bırakılmadı. Derlenme ünitesinden taburcu edilemeyip hastaneye yatı̧ıı gereken hastayla karşılaşılmadı. Gruplarda saptanan yan etkiler (n-\%) tablo 8'de listelenmiştir.

Uygulamayi yapan endoskopist kolonskopi sonrasında işlemden memnuniyetini basit bir skalayı esas alarak puanladı (Skala / 1. Kötü, 2. Orta, 3. İyi). Grup I'de 3 hasta kötü (\%10), 9 hastada orta (\%30), 18 hastada ise iyi (\%60) olarak değerlendirilirken Grup II'de 9 hasta orta (\%30), 21 hasta ise iyi (\%70) olarak nitelendi. Değerlendirmenin ağırlıklı matematiksel ortalaması

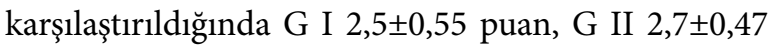
puan aldı. Aralarındaki fark istatistiksel olarak anlamlı bulunmadı ( $\mathrm{p}=0,058 / \mathrm{p}>0,05)$. İşlem üzerinden 24 
Tablo 6. Gruplar Arası VAS, RSS, OAA/S ve Kan Şekeri Sonuçlarının Karşılaştırılması

\begin{tabular}{|l|c|c|c|c|c|}
\hline & \multicolumn{2}{|c|}{$\begin{array}{c}\text { Grup I } \\
\text { (Propofol + } \\
\text { Ketamin) }\end{array}$} & \multicolumn{2}{c|}{$\begin{array}{c}\text { Grup II } \\
\text { (Propofol + } \\
\text { Petidin) }\end{array}$} & \multirow{2}{*}{ P Değeri } \\
\cline { 1 - 5 } & Ortalama & SD & Ortalama & SD & \\
\hline VAS (işlem sırasında) & 1,36 & 1,14 & 2,13 & 1,49 & $0,041^{*}$ \\
\hline VAS (derlenme ünitesi 5. dk) & 1,03 & 0,83 & 1,46 & 0,85 & 0.056 \\
\hline RSS (işlem sırasında) & 4,43 & 1,87 & 3,28 & 1,51 & $0,043^{*}$ \\
\hline RSS (derlenme ünitesi 5. dk) & 4,11 & 1,29 & 2,87 & 1,09 & $0,000^{* *}$ \\
\hline OASS (derlenme ünitesi 5. dk) & 3,33 & 0,94 & 4,46 & 1,03 & $0,041^{*}$ \\
\hline Kan Şekeri mg/dL. (öncesi) & 98,17 & 11,62 & 95,87 & 11,94 & 0,453 \\
\hline Kan Şekeri mg/dL. (sonrası) & 104,77 & 12,14 & 93,11 & 9,39 & $0,004^{*}$ \\
\hline
\end{tabular}

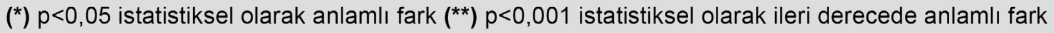

saat geçtikten sonra telefonla iletişim kurulan hastalar da kolonoskopi deneyimlerini aynı skalayı esas alarak değerlendirdiler; G I'de 3 hasta kötü (\%10), 2 hasta orta $(\% 6,66), 25$ hasta iyi $(\% 83,33), \mathrm{G}$ II'de ise 2 hasta kötü $(\% 6,66), 1$ hasta orta $(\% 3,33), 27$ hasta ise iyi $(\% 90)$ olarak

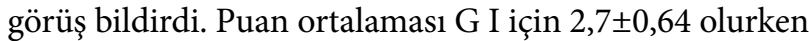
G II'de 2,8 $\pm 0,53$ bulundu. Aradaki fark istatistiksel olarak anlamlı değildi ( $\mathrm{p}=0,513 / \mathrm{p}>0,05)$. Endoskopist ve hastaların değerlendirme sonuçları tablo 9'da özetlenmiştir.

\section{TARTIŞMA}

Kolorektal kanser ABD’nin yanısıra pekçok batı ülkesinde ve ülkemizde erkeklerde akciğer ve prostat, kadınlarda ise akciğer ve meme kanserinden sonra en sik görülen kanserdir (21). Kolon ile ilgili patolojilerin tarama, tanı ve tedavisinde en önemli silah endoskopi / kolonoskopidir. Son birkaç yılda ABD'de yapılan endoskopik işlemler 4 kat artmış olup rutin endoskopilerin \%98'i sedasyon altında yapılmaktadır (22).

Sedasyon bilinç durumunun ve bazı reflekslerin bir takım ilaçlar yardımıyla farklı düzeylerde baskılanmasıdır. Kolonoskopi nispeten ağrılı, uzun süren ve rahatsızlık veren invazif bir işlem olduğundan sedasyon, ağrı ve anksiyeteyi azaltarak hasta konforunun artmasina olanak tanır. Tüm bunların yanısıra hastanın istenmeyen hareketlerinden oluşabilecek fiziksel zararlar da en aza indirgenir, endoskopistin detaylı bir tetkik yapabilmesi için uygun koşulları sağlayarak işlem kalitesini ve başarısını arttırir (5). Sedasyon sirasinda analjeziyle birlikte spontan solunumun devam ettirilmesinin yanısıra hastanın sözlü emirlere ya da hafif dokunma uyarısına yanıt vererek kendisinden istenilenleri yerine getirmesi de önemlidir. American Society of Anesthesiologist'e göre bu düzey "orta" ya da "bilinçli sedasyon" olarak tanımlanır. "Bilinçli Sedasyon" yeterli kardiyopulmoner fonksiyonu devam ettirirken komut ve taktil uyaranlara amacina uygun cevaba izin veren ve hastanın rahatsızlık verici işlemleri rahat tolere etmesine olanak sağlayan düzeydir $(17,23)$.

Hızlı indüksiyon ve derlenme bu sürecin önemli komponentleri olup özellikle günübirlik hasta sirkülasyonunun yüksek olduğu ünitelerde daha da önem kazanır. Kullanılacak sedasyon ajanının minimum yan etkiyle hızlı başlangıçlı, etkili olması, derlenmenin çabuk ve maliyetin ekonomik olması istenir. Günümüzde tüm bu özelliklerin tümünü taşıyan bir ilaç bulunmadığından farklı ilaçların birlikte kullanımı tercih edilmektedir (24).

2000-2013 arasında ABD. de yapilan 1.385.436 kolonoskopinin 1.057.719 unda midazolam, 614.707 sinde fentanil, 421.456 sinda meperidin, 125.899 unda ise propofol kullanılmıştır. Günümüzde propofol/fentanil kullanımı hızla artarken meperidin kullanımı azalmakla birlikte konvansiyol yöntemin bir parçası olarak önemini hala korumaktadır (25). Kolonoskopi sırasında komplikasyon işlemin kendisin- 
Tablo 7. Derlenme Ünitesi 5. dakika Skala Değerlendirmelerinin Gruplara Göre Dağııımı

\begin{tabular}{|l|r|l|c|c|c|c|}
\hline & & & \multicolumn{2}{|c|}{ Grup I (P + K) } & \multicolumn{2}{c|}{ Grup II (P + P) } \\
\hline Skala & $\mathbf{P}$ & & Sayı & $\%$ & Sayı & $\%$ \\
\hline RSS & $\mathbf{1}$ & Endişeli, huzursuz & 0 & 0 & 2 & $\% 6,66$ \\
\cline { 2 - 7 } (lit) & $\mathbf{2}$ & Koopere, oryante, sakin & 4 & $\% 13,33$ & 9 & $\% 30$ \\
\cline { 2 - 7 } & $\mathbf{3}$ & Emirlere uyar & 5 & $\% 16,66$ & 9 & $\% 30$ \\
\cline { 2 - 7 } & $\mathbf{4}$ & Uyaranlara canlı cevap & 7 & $\% 23,33$ & 8 & $\% 26,66$ \\
\cline { 2 - 7 } & $\mathbf{5}$ & Uyaranlara yavaş cevap & 14 & $\% 46,66$ & 3 & $\% 10$ \\
\cline { 2 - 7 } & $\mathbf{6}$ & Uyarana cevap yok & 0 & 0 & 0 & 0 \\
\hline \multirow{3}{*}{ OAA/S } & $\mathbf{5}$ & Adı normal tonda söylenince yanıt & 7 & $\% 23,33$ & 18 & $\% 60$ \\
\cline { 2 - 7 } & $\mathbf{4}$ & Adı normal söylenince uyuşuk yanıt & 8 & $\% 26,66$ & 9 & $\% 30$ \\
\cline { 2 - 7 } & $\mathbf{3}$ & Adı yüksek sesle ve tekrarlanınca & 3 & $\% 10$ & 2 & $\% 6,66$ \\
& & cevap & & & & \\
\cline { 2 - 7 } & $\mathbf{2}$ & Sallama dürtmeyle yanıt & 12 & $\% 40$ & 1 & $\% 3,33$ \\
\cline { 2 - 7 } & $\mathbf{1}$ & Sallamaya dürtmeye yanıtsız & 0 & 0 & 0 & 0 \\
\hline
\end{tabular}

den çok kullanılan sedasyon ajanlarından kaynaklanmaktadır $(6,26)$. Özellikle ülkemizde de anestezist olmayan hekimlerce spesifik antagonisti (flumazenil) bulunmasından ötürü en sık tercih edilen midazolam (27), hafızanın geri dönme süresini uzatır, uzun dönemde davranışsal değişikliklere, kognitif disfonksiyona ve en önemlisi de solunum depresyonuna, paradoksal ajitasyona neden olabilir $(4,5)$. Sonuçta hedeflenenin aksine işlem uzar, taburculuk geçikir (27). Son yıllarda farmakodinamik özelliklerinden ötürü benzodiazepinlerin yerini propofol almaktadır $(6,16,27,28)$. Propofolun hızlı indüksiyon, hızlı derlenme ve sedasyon derinliğinin kolay ayarlanması (6) ve antiemetik özelliği (29) sedasyon ajanı olarak tercih edilmesini sağlar. Ancak bu ilacın da doza bağımlı olarak arttan ciddi yan etkileri vardır $(7,8)$. Sedasyon dozlarında bile gelişebilen bradikardi, hipotansiyon gibi hemodinamik instabilite ve solunum eforunda azalma propofolu ideal sedasyon ajanı yapmaktan uzaklaştırır (30). Tüm bunların yanısıra propofolün analjezik özelliği yoktur ve amnezik özelliği zayıftır (31). Benzer şekilde benzodiazepinler de analjezik özellik taşımaz (9). Bu gerekçelerle tek başlarına kullanımında ya hipnozu derinleştirmek amacıyla yüksek doz uygulanırlar ki bu da yan etkilerin kaçınılmaz olarak artmasıyla sonuçlanır, ya da bir analjezik eklenir $(16,32)$.

Hastanelerde ağrı tedavisinde yaygın kullanılan opioidler (33) gün geçtikçe günübirlik işlemlerde de tek başına ya da sıklıkla diğer hipnotiklerle birlikte kullanılmaktadır $(9,13,33,34)$. Ancak opioidlere verilen yanıtta ve yan etkilerin görülmesinde geniş bir kişisel cevap aralığı vardır ve olası etkileri ön görmek herzaman mümkün olmaz (34). Opioidler merkezi sinir sistemini deprese ederek solunum yetmezliği oluşturabilir. Benzodiazepinlerle veya propofol ile birlikte kullanımında solunum yetmezliği oluşturma olasılığ artar (35). Özellikle uygun koşullar ya da anestezist olmadan yapilan sedasyonlarda bu durum istenmeyen sonuçlar doğurabilir. Bu gerekçeyle bazı ülkelerde propofolun kullanımına sadece belirli klinik koşullarda ve anestezistin varlığında izin verilmektedir (36). Opioidlerin kullanımı arttıkça herkesce bilinen uzamış uyanma, sersemlik hissi, başdönmesi, ileus, konstipasyon, bulantı-kusma, kaşıntı, üriner retansiyon, azalmış kardiyak output vb. istenmeyen etkilerin yanı sıra şimdiye dek çok da irdelenmeyen bazı ciddi yan etkilerin önemi anlaşılmaktadır (37). Akut tolerans ve hiperaljezi, solunum kaslarında sertlik, immün hücrelerin fonksiyonlarının baskılanması (immun supresyon), histamin salgısını arttırarak oluşturduğu bronkospazm, bazı hayati organ damarlarında (örn akciğer) vasokonstruksiyon ve hipersensitivite reaksiyonları bunların başlıcalarıdır $(37,38)$. Tüm bu gerekçelerle son yıllarda opioidlerin bu derece yaygın kullanım gerekliliği sorgulanmaya başlanmış ve opioid kullanmadan da analjezinin farklı ilaçlarla (deksmedetomidin, kloni- 
Tablo 8. Gruplarda Saptanan Yan Etkiler

\begin{tabular}{|l|c|c|c|c|}
\hline & \multicolumn{2}{|c|}{$\begin{array}{c}\text { Grup I } \\
\text { (Propofol + } \\
\text { Ketamin) }\end{array}$} & \multicolumn{2}{c|}{$\begin{array}{c}\text { Grup II } \\
\text { (Propofol + } \\
\text { Petidin) }\end{array}$} \\
\hline Hipotansiyon & Sayı & $\%$ & Sayı & $\%$ \\
\hline Hipertansiyon & 1 & $\% 3,33$ & 3 & $\% 10$ \\
\hline Bradikardi & 0 & 0 & 1 & $\% 3,33$ \\
\hline Taşikardi & 1 & $\% 3,33$ & 2 & $\% 6,66$ \\
\hline Hipoksi Eğilimi & 0 & 0 & 1 & $\% 3,33$ \\
\hline Hipoksi & 0 & 0 & 2 & $\% 6,66$ \\
\hline Solunum Depresyonu-Apne & 0 & 0 & 0 & 0 \\
\hline Ağrı (İşlem sırasında) & 1 & $\% 3,33$ & 6 & $\% 20$ \\
\hline Ağrı (İşlem sonrasında) & 0 & 0 & 1 & $\% 3,33$ \\
\hline Bulantı & 1 & $\% 3,33$ & 4 & $\% 13,33$ \\
\hline Kusma & 1 & $\% 3,33$ & 2 & $\% 6,66$ \\
\hline Genel Halsizlik & 3 & $\% 10$ & 2 & $\% 6,66$ \\
\hline Baş Ağrısı, Sersemlik & 3 & $\% 10$ & 1 & $\% 3,33$ \\
\hline Uyanırken rüya görme, & 3 & $\% 10$ & 0 & 0 \\
\hline sayıklama & & & & 0 \\
\hline
\end{tabular}

din, lidokain, magnezyum, ketamin vb.) sağlanabileceği gösterilmiştir (37). Ketamin hipnotik, amnestik ve sedatif özelliklerinin yanı sıra santral etkili güçlü bir analjeziktir. Anestezik dozlarda tek başına kullanıldığında kalp hızını, kan basıncını arttırır, bulantı-kusmaya, halüsinasyonlara ve disforiye neden olabilir (11). Tüm bu gerekçelerle sedasyon amaçlı kullanımı uygulama yolu kolaylığı (oral, im, iv, intranasal) olan eski bir ilaç olmasına karşın acil koşullar dışında yaygınlık kazanmamıştır (39). Ancak son yıllarda çok daha düşük dozlarda yan etkisinin çok daha az olduğu ve analjezik olarak rahatlıkla kullanılabileceği gösterilmiştir (40). Ketaminin subhipnotik dozlarda benzodiazepinlerle veya propofolle birlikte kullanımı istenmeyen yan etkilerini azaltmış özellikle propofolle sinerjik etki ederek birbirlerinin kötü etkilerini antagonize etmesini sağlamıştır (12, 26, 41-44).

Biz de bu çalışmamızda tanısal kolonoskopi hastalarında propofolle aynı enjektörde 1:3 oranında kombine edilen nonopioid bir seçenek olan ketaminin (ketamin + pro- pofol / ketofol) klinik etkileriyle; kullanımı azalmakla beraber hala konvansiyonel yöntemin ve hastanelerde uygulanan postoperatuvar analjezinin önemli bir parçası olan petidinin propofolle kombinasyonunu karşılaştırdık. Çalışmamızda sedasyon düzeyini belirlemekte en sık kullanılan skalalardan biri olan Ramsey Sedasyon Skalası (RSS) (18) kullanılmış olup bilinçli sedasyon olarak da adlandırılan RSS 3-4 düzeyi hedeflenmiştir (17,23). Her iki grupta da hedeflenen düzey tutturulmuş ve işlem sırasında sedasyon ilaçları kaynaklı sorunla karşılaşılmamıştır. G I'de uygulanan dozlarda hedef RSS'ye daha kısa sürede ulaşılmış (kısa indüksiyon süresi) ve işlem süresince G II'ye oranla RSS daha yüksek devam etmiştir. Ayrıca işlem sırasında sedasyonunun derinleşme eğilimi nedeniyle infüzyon dozu azaltılmıştır. Kısa indüksiyon süresi Tutal (41) ve Arora (45)'nın da çalışmalarında da saptanan bir bulgudur. Derlenme süresi açısından ise propofolle yapılan bazı çalışmalarda indüksiyonda daha düşük doz kullanılmasına karşın propofolun kısa klinik etkisi nedeniyle yapılmak zorunda kalınan ara dozlarla derlen- 
Tablo 9. Endoskopist ve Hastaların Memnuniyet Değerlendirme Sonuçları

\begin{tabular}{|r|l|c|c|c|c|c|}
\hline & & \multicolumn{2}{|c|}{$\begin{array}{c}\text { Grup I } \\
\text { (Propofol + } \\
\text { Ketamin) }\end{array}$} & \multicolumn{2}{c|}{$\begin{array}{c}\text { Grup II } \\
\text { (Propofol + } \\
\text { Petidin) }\end{array}$} & $\begin{array}{c}\text { p } \\
\text { Değeri }\end{array}$ \\
\hline Puan & & Sayı & $\%$ & Sayı & $\%$ & \\
\hline $\mathbf{1}$ & Kötü & 3 & $\% 10$ & 0 & 0 & \\
\hline $\mathbf{2}$ & Orta & 9 & $\% 30$ & 9 & $\% 30$ & \\
\hline 3 & lyi & 18 & $\% 60$ & 21 & $\% 70$ & \\
\hline $\begin{array}{r}\text { Endoskopist } \\
\text { memnuniyet }\end{array}$ & 2,5 & $\pm 0,55$ & 2,7 & $\pm 0,47$ & 0,058 \\
\hline Puan & & & & & & \\
\hline $\mathbf{1}$ & Kötü & 3 & $\% 10$ & 2 & $\% 6,66$ & \\
\hline 2 & Orta & 2 & $\% 6,66$ & 1 & $\% 3,33$ & \\
\hline 3 & Iyi & 25 & $\% 83,33$ & 27 & $\% 90$ & \\
\hline Hasta memnuniyet & 2,7 & $\pm 0,64$ & 2,8 & $\pm 0,53$ & 0,513 \\
\hline
\end{tabular}

$\left(^{*}\right) p<0,05$ istatistiksel olarak anlamlı fark $\left(^{* *}\right) p<0,001$ istatistiksel olarak ileri derecede anlamlı fark

me süresinin uzadığg gösterilmiştir (46-48). Ketofolle yapılan çalışmalarda ise farklı sonuçlar elde edilmiştir. Tandon (48), Fabbri (49), Tang (50) gibi bazı araştırmacilar propofole ketamin eklenmesiyle derlenme süresinin kısaldığını iddia ederken Andolfatto (44), Miner (51), Yuce (52), Mortero (53) gibi diğer yazarlar ise tam aksine sürenin uzadığını söylemektedir. Cillo (54) ve Badrinath (12) ise yaptıkları araştırmalarda ketamin dozu arttıkça derlenme ve taburcu sürelerinin uzadığını göstermişlerdir. Bizim çalışmamızda da toplam olarak daha az propofol kullanılmış (düşük doz propofol) olmasına karşın derlenme süresi uzamıştır (uzamış derlenme süresi). Derlenme süresi konusunda G II'de ise indüksiyon nispeten geç olmuş (uzamış indüksiyon süresi), işlem sırasında RSS daha yüzeyel saptanmış ve bazı hastalarda doz arttırımı gerekmiştir. G II'de özellikle indüksiyon süresinin uzaması her ne kadar hasta ve hekim memnuniyet puanlarına yansımamış olsa da işlem sırasında herşeyin hazır olduğu ortamda ilaçların etki etmesini beklemek sözel eleştiri almıştır. Derlenme süresi ise, G II'de G I'e oranla belirgin kısadır. İndüksiyon süresinin uzamış olmasına karşın hastanın ve özellikle hekimin memnuniyetini oluşturan en önemli komponentlerden birisi de bu özelliktir. Çalışmamızda demografik bulgular ve kolonoskopi süresi açısından gruplar arasında istatistiksel anlamlı fark yoktur. Üstelik hipnotik ajan olan propofol toplamda G II'de daha yüksek doz kullanılmıştır. Bu nedenle saptanan süre farklılıklarını tercih edilen ilaçdan (ketamin/petidin) kaynaklandığını söylemek yanlış olmaz. Bundan ketaminin kullandığımız düşük dozlarda bile kısmen hipnotik etki gösterdiğini en azından propofolün hipnotik etkisini arttıracak şekilde aditif katkıda bulunduğunu düşünmekteyiz.

Ketamin/propofol kombinasyonuyla yapılan çalışmalarda farklı konsantrasyonlar kullanılmıştır; 1:1 (44, $46,51,52,55-57), 1: 2$ (46, 58-59), 1:4 (44, 51), 1:5 $(12,54)$ bunlardan bazılarıdır. 1995 yılında Anesthesiology dergisinde yayınlanan makalesinde Hui tek başına kullanımda ketaminin ED50'sini 0,39 mg/kg., propofolun ED50'sini 1,1 mg/kg. ve bunlarının kombinasyonunun ED50'sini ise ketamin $0,21 \mathrm{mg} / \mathrm{kg}$. ve propofol $0,63 \mathrm{mg} / \mathrm{kg}$. (1:3) olarak yayınlamıştır (60). Biz de çalışmamızda ketamin/propofol doz seçimini bu makaleden referans alarak ve diğer bazı yazarlar gibi 1:3 olarak belirledik $(12,43,45,47,49,54,61,62)$. Ancak çalışmamız sonrasında RSS’nin artma eğiliminde olması ve uzamış derlenme süresi nedeniyle, kısalmış indüksiyon süresi gibi bir avantaj sağlamasına karşın kullanılan ketamin dozunun bir kez daha gözden geçirilmesi gerektiğini düşünmekteyiz.

Propofolle yapılan bir çalışmada Hug, hastalarda hipotansiyonun yaklaşı \% 15.7 oranında geliştiğini ve genelde uygulamayı takip eden 10 dakikalık periyodda görüldüğünü saptamıştır. Ek olarak bradikardi görül- 
me sıklı̆̆ını \% 4.8 olarak belirlemiş, bunun da yaklaşık \%40'ının yine ilk 10 dakikalık dönemde geliştiğini iddia etmiştir (8). Hug' a göre her iki belirtinin de birlikte gelişmesi oldukça nadir olup (\% 1.3) hemodinamik komplikasyonların sadece \%0.2 si medikal tedavi gerektirir. Özellikle hipotansiyon yüzdesinin yaşlılarda, kadınlarda, Kafkas irkında ve opioid verilenlerde sık olduğu, bradikardinin ise opioid verilenlerin yanı sira beta bloker kullanan hastalarda daha çok görülebildiğini belirlemiştir (8).

Çalışmamızda hemodinamik parametrelerden OAB açısından; G I'de grup içi OAB bir miktar düşmekle birlikte fark istatistiksel anlamlı değildi. G II'de ise grup içi değerlendirmede 5. dk OAB işlem öncesine göre anlamlı düştü ancak hemen ertesinde işlemin başlamasıyla $\mathrm{OAB}$ hızla normal değerlere ulaştı. Gruplar arası karşılaştırmada fark saptanmadi. Bireysel olarak G I'de 1 hastada (\%3.33), G II'de ise 3 hastada (\%10) hipotansiyon saptan$\mathrm{d}$, bunlardan biri ancak $(\% 1,66)$ medikal tedaviye (Efedrin) yanit verdi. Tandon (48), Abdellatif (46), Nengroo (63) çalışmalarında propofole ketamin eklenmesinin daha stabil hemodinami oluşturduğunu ve hipotansiyon yüzdesini belirgin azalttığını göstermişlerdir. Ketaminin propofole olumlu katkısı konusunda negatif görüş bildiren araştırmacı yok denecek kadar azdır $(42,61)$. Gruplar arasindaki fark olmasa da G II'de 5. dakikada saptanan hipotansiyonu ve biri tedavi gerektiren 3 hipotansif hastayı ketaminin hipotansiyondan koruyucu sempatomimetik etkisinin eksikliğine bağlayabiliriz. Ek olarak G II'de kullanılan petidin her ne kadar düşük dozda olsa da histamin salınımına, bu da vazodilatasyona neden olarak hipotansiyon eğilimine neden olabilir (64). Ancak G II'de indüksiyon süresinin daha uzun olmasindan ötürü kolonoskopiye nispeten geç başlanmış olmasının da işlemden kaynaklanan sempatik uyarının gecikmesine neden olabileceği, bunun da hipotansiyona katkıda bulunabileceği akıldan çıkarılmamalıdır. Çalışmamızda her iki grupta da grup içi ve gruplar arası karşılaştırmada $\mathrm{KAH}$ açısından fark saptamadık. G I'de 1 hastada (\%3.33) bradikardi gelişirken G II'de 2 hastada $(\% 6,66)$ görüldü ve bunlarda sadece eş zamanlı hipotansiyon gelişen bir hastada $(\% 1,66)$ ilaç tedavisi gerekti. Abdellatif ve Tang'ın çalışmalarında ketofol grubunda bradikardi yüzdesinin azaldığını paylaşmaktadırlar $(46,50)$. Tüm bunlara ek olarak G I'de daha tatminkar olmakla birlikte diğer çalışmalara oranla her iki grupta da oldukça stabil olan hemodinaminin ve çok daha düşük hipotansiyon ve bradikardi yüzdelerinin hazırlık döneminde istemsiz dehidrate kalan (oral alım kısitlaması, lavman vb.) bu grup hastaya kolonoskopi s1- rasında yeterli hatta agresif sıvı transfüzyonu yapmamıza da bağlayabiliriz. Kolonoskopi hastalarında indüksiyon sonrası gelişen hipotansiyonun dehidratasyondan kaynaklanabileceği, bu hastalarda elektrolit dengesizliklerinin de bulanabileceği her zaman hatırda tutulmalıdır (23).

Sedasyon uygulamaları sirasında propofole bağlı sorun oluşturan ve ilacın yaygın kullanımını engelleyen komplikasyonların en tehlikelileri respiratuvar sistemle ilgili olanlardır. Bunlar sıklıkla solunum sayısının ve/veya derinliğinin azalması ve apnedir. Ketaminin propofole eklenmesindeki amaçlardan birisi de girişim gerektiren solunumsal komplikasyonları azaltmaktır. Bu konuda yapılan çalışmalarda farklı sonuçlar elde edilmiştir. Tandon (48), De Oliveira (65), Fabbri (49), Abdellatif (46), Tang (50) gibi çok sayıda araştırmacı ketamin eklenmesinin solunumsal komplikasyon yüzdesini azalttığını iddia etmişlerse de Yüce (52), Andolfatto (44) gibi yazarlar ise etkisi olmadığını söylemektedir. Hatta aynı yazar grubunun farklı çalışmalarında aleyhte (66) ve lehte (67) sonuçlar elde edilmiştir. Miner (51) ve Badrinath (12) gibi araştırmacilarsa bunun ketamin/propofol konsantrasyonuyla ilişkili olabileceğini vurgulamışlardır. Badrinath yaptığ 1 çalışmada propofol grubunda \%52 gibi yüksek komplikasyon oranı verirken benzer oranları 1:10 (\%56) ve 1:5 (\%40) ketamin/propofol karışımlarında da saptamıştır. Oysa aynı çalışmada bizim de tercih ettiğimiz 1:3.3 konsantrasyonlarda solunumsal komplikasyonlar \%20'ye inmektedir (12). Tedavideki ortak görüş ise destekleyici önlemlerin yanı sıra propofolün kesilmesinin sorunu kısa sürede düzelttiğidir (68). Çalışmamızda solunumsal ciddi yan etkilere her iki grupta hemen hiç rastlanmamış olup ne grup içi, ne de gruplar arası SpO2 karşılaştırmalarinda fark saptanmadi. Bu durumun hem hedeflenen sedasyon düzeyinin orta düzeyde seçilmesinden, hem de G I'de seçilen ketamin/propofol konsantrasyonun 1:3 olmasindan, G II'de ise kullanılan opioidin farmakodinamik özelliklerinden ve dozunun oldukça düşük olmasından kaynaklandığını düşünmekteyiz. Ek olarak kullanılan tüm ilaçların IV yavaş perfüzyon olarak uygulandığı ve toplam dozlarının da oldukça düşük olduğu hatırda tutulmalıdır. Ayrıca tüm hastalara işlem sırasında rutin 2 lt/ dk. nasal $\mathrm{O} 2$ uygulanması da olumlu katkıda bulunmuş olabilir.

Propofolun hem respiratuvar hem de hemodinamik komplikasyonlarının görülmesinde uygulama kaynaklı en önemli risk faktörleri propofolun infüzyon hızı, toplam dozu ve opioid eklenmesidir $(42,67)$. Çalışmamızda G'I de opioide alternatif olarak ketamin tercih edilmişken 
G II'de de petidin oldukça düşük dozda kullanılmıştır. Ek olarak her iki grupta da propofol yavaş infüzyon şeklinde verilmiş olup toplam doz da oldukça düşüktür. Tüm bu gerekçelerin çalışmamızda G II'de minimal hemodinamik yan etki görülmesinde ve her iki grupta da hiçbir respiratuvar yan etki görülmemesinde olumlu katkıda bulunduğunu düşünmekteyiz.

İşlem sırasındaki VAS değerleri ortalaması G I’e oranla G II'de daha yüksek saptandı. Ek olarak G I'de sadece 1 hasta ağrı yakınmasında bulunmuşken bu sayı G II'de 6 kişi olarak gerçekleşti. Çalışmamızda saptadığımız bu durumun $\mathrm{G}$ I'de kullanılan ketaminin daha etkin analjezi sağlamasıyla olduğunu düşünmekteyiz. Mortero (53) yaptığı bir çalışmada propofole ketamin eklenmesinin VAS değerlerini düşürdüğünü göstermiştir. Yüce de farklı hasta gruplarında benzer sonuçlar saptamıştır (52). G II'deki RSS’nin nispeten düşük ve işlem sonunda OASS'nin daha yüksek olması derlenmenin çabuk olmasının somut göstergeleri olmakla birlikte daha yüzeyel sedasyona da işaret eder. Yüzeyel sedasyonun G II'deki hastaları emosyonel olarak da etkiyebileceğini ve subjektif bir duygu olan ağrı algısını da negatif etkileyebileceğini düşünmekteyiz. Ek olarak G'II de kullanılan narkotik anajeziklere verilen kişisel yanıt farklılıklarının çok geniş bir aralıkta olduğu da hatırlanmalıdır (34). Her ne kadar her iki grupta da ortalama VAS değerleri ağrı sınırının altında kalmış olsa da yapılan kolonoskopinin tanısal olduğu ve ciddi ağrı oluşturmasının beklenmediği, terapötik işlemlerde diagnostiklere oranla daha fazla analjezi gerekebileceği unutulmamalıdır (28). Ancak işlemin tanısal olması, hastanın derlenme süresinin kısa olması ve işlem sonrası komplikasyonların görece olarak G II'de daha az görülmesi VAS yüksekliğinin hasta/hekim memmuniyetine negatif yansımasını engellemiştir.

Çalışmamızda kan şekeri değerleri karşılaştırdığında her iki grupta işlem öncesi ve grup içlerinde işlem öncesi ve sonrası değerlerde istatistiksel anlamlı fark yokken işlem sonrası G I ve II arasındaki karşılaştırmada istatistiksel anlamlı fark saptanmıştır. İndüksiyon ajanlarının (propofol, ketamin, etomidat) kan şekerine etkilerin inceleyen oldukça yeni tarihli bir araştırmada propofolün kan şekeri düzeyine etki etmediği gösterilmiştir (69). Propofol muhtemelen beta adacık hücrelerindeki potasyum duyarlı adenozin trifosfat kanallarını (KATP) inhibe ederek insülin sekresyonunu arttırır ve belirgin şekilde insülin sensitivitesini zayıflatır. Ek olarak da glukoz metabolizmasına etki eden sempatik uyarıları da köreltir. Ketaminin etkisi ise oldukça ilginçtir. Aynı çalışmada ketaminin indüksiyon dozunun $(2 \mathrm{mg} / \mathrm{kg}$ ) yapılmasını takiben 30-60 dk. sonra kan şekerinin yüksel- diği gösterilmiştir (69). Bir başka çalışmada ise şuuru açık tavşanlarda ketaminin kan şekerine etkisinin ikili (dual) olduğu ve doza bağımlı değişebildiği iddia edilmiştir (70). Bu çalışmada düşük doz ketamin (166 $\mu \mathrm{gr} /$ kg) 15-30 dakikada hiperglisemi oluştururken daha yüksek dozların (1-2 mg/kg) hipoglisemi oluşturduğu, doz daha da arttırıldığında ise $(4 \mathrm{mg} / \mathrm{kg}) \mathrm{kan}$ şekerini 60 dakikaya dek etkilemediği ancak 2 saatten sonra belirgin yükselttiği görülmüştür (70). Ketaminin akut hiperglisemik etkisi, kısmen insülin, kortikosteron ve ACTH gibi glukoregulatuvar hormonların alfa 2 adrenoreseptör bağımlı değişimlerinden kaynaklanır (69). 2 $\mathrm{mg} / \mathrm{kg}$ ketamin enjeksiyonundan sonra plasma katekolamin seviyeleri istirahate göre \%50 artmıştır (69). Ketaminin hiperglisemiyi a2 adrenoreseptörler üzerinden oluşturduğu düşünülmektedir $(69,70)$. Aynı çalışmada selektif $a 2$ reseptör antagonistlerinin ketaminin hiperglisemik etkisi doza bağlı antagonize ettiği gösterilmiştir (70). Diğer bir çalışmada ise ketaminin normal glukoz metabolizması olan farelerde kan şekerine etki etmediği ancak diyabet oluşturulmuş farelerde belirgin hiperglisemi geliştiği gösterilmiştir (71). Çalışmamızda G I'de kan şekeri yükselmesi ketamin kullanılmamış olmasına karşın sadece $\% 5$ düzeyinde kalmıştır. Bunda diyabetik hastaların çalışma grubu dışında bırakılmış olmasının yanı sıra eş zamanlı propofolle birlikte kullanılmış olmasının da etkisi olduğunu düşünmekteyiz. Kanımızca propofol aynı kardiyak ve respiratuvar sistemde olduğu gibi metabolik etkilerde de sempatik uyarıyı körelterek dengeleyici rol oynamakta, kan şekerinin daha yüksek değerlere ulaşmasını engellemektedir. Her ne kadar çalışmamızda veriler hiperglisemi sınırına ulaşmasa da özellikle ketamin kullanılacak diyabetik hastalarda oluşabilecek kan şekeri yükselmeleri konusunda dikkatli olunması gerektiği ve postoperatif dönemde kan şekeri kontrolünün uygun olacağı düşüncesindeyiz.

Ketaminin iyi bilinen yan etkilerinden birisi de bulantı ve kusmadır. Strayer ve arkadaşları 2008 yılında yaptıkları bir çalışmada erişkinlerde bu oranın \%5-15 arasında değiştiğini söylemişlerdir (72). Ketofolle propofolü karşılaştıran çalışmalarda ise farklı sonuçlar elde edilmiştir. Abdellatif (46), Aydoğan (47), Yuce (52), ve De Oliveira (65) gibi araştırmacılar ketofolde bulantı ve kusmanın oranının arttığını söylerken Miner (51), Fabbri (49) gibi araştırmacılar ise tam aksini iddia etmişlerdir. Bizim çalışmamızda günübirlik işlemlerde hastaları en çok rahatsız eden bulgulardan biri olan bulantı $(\mathrm{G} I=\% 3,33$, $\mathrm{G} \mathrm{II}=\% 13,33)$ ve kusma $(\mathrm{G} \mathrm{I}=\% 3,33, \mathrm{G} \mathrm{II}=6,66)$ G I'e oranla G II’de daha sık görülmüştür. Antiemetik özelliği 
olduğu bilinen propofolun daha yüksek dozda kullanılmasına karşın bu durum yine G II'de kullanılan opioide kişisel cevap farklılıklarını, opioid yan etkilerini ve daha yüzeyel sedasyonun neden olduğu emosyonel faktörleri akla getirir $(34,37)$. Kanımızca burada hatırlanması gereken en önemli faktörün G II'de narkotik analjezik kullanılmış olduğu gerçeğidir. Klasik bilgi olarak bulantı ve kusma narkotik analjeziklerin en önemli yan etkilerindendir $(34,37)$.

Çalışmamızda tıbbi ekipçe önemli kabul edilen ve ketaminin yaygın kullanımını sınırlayan uyanırken rüya görme, sayıklama gibi psikomimetik yan etkiler G I'de \%10 (G II \%0) oranında saptanmıştır. Farklı ketamin/propofol kombinasyonlarıyla yapılan çalışmalarda psikomimetik yan etki oranlarını Miner (51) 1:1'de \%21.2, 1:4'de \%10.4, Badrinath (12) 1:3'de \%16, 1:5 ve 1:10 da \%8, Abdellatif (46) 1:1'de \%2.9 olarak bildirmişlerdir. Bazı çalışmalarda propofolün GABA-A reseptör aktivasyonu aracilığıyla ve NMDA reseptörlerini suprese ederek ketamine bağlı istenmeyen psikomimetik aktiviteyi nötralize ettiği iddia edilmiştir $(73,74)$. Bir diğer çalışmada ise psikomimetik etkilerden korunmak için kullanılan ketamin dozunun risk sınırı kabul edilen değerlerin altında $(5 \mu \mathrm{gr} / \mathrm{kg} / \mathrm{dk})$ olması önerilmektedir (75). Bu nedenlerle ketamin dozunun azaltılıp propofol dozu arttırıldıkça psikomimetik belirtilerin azalacağ 1 hatta bir noktadan sonra görülmeyeceği düşünülmektedir. Psikomimetik yan etki görülmesi oranımız benzer çalışmalardan düşük olmakla birlikte propofolun varlığına ve ketaminin düşük doz uygulanmasına karşın (1:3) tam olarak önüne geçilememiştir. Biz psikomimetik yakınmaların hastaların derlenme süresinin uzamasında ve taburculuğun geçikmesinde asıl neden olduğuna ve bunun da ketamine endişeyle yaklaşılmasına yol açtı̆̆ına inanıyoruz.

İşlem sonu değerlendirmede hasta ve endoskopist memnuniyeti yönünden G II'nin puanları bir miktar yüksek olmakla birlikte gruplar arasında istatistiksel anlamlı bir fark saptanmadı. G I'de hızlı indüksiyon, daha stabil hemodinami, daha yüksek analjezi düzeyi beğeni toplarken derlenme süresinin uzunluğu ve istenmeyen bazı psikomimetik yan etkiler eleştirilere neden oldu. Aynı şekilde uzamış indüksiyon, bulantı-kusmanın daha fazla görülmesi, ağrı şikayetinin daha belirgin olması G II'deki hoşlanılmayan bulgularken işlem sırasında çok daha rahat iletişim kurulabilmesi, hızlı derlenme, işlem sonrası periyodun daha kısa süreli olması ve rahat geçmesi belirgin üstünlükler olarak kabul edildi.

Son olarak bu çalışmanın bazı sınırlamaları olduğunu da unutmamak gerekir. Öncelikli olarak diğer çalışmalarla uyum gösterse de hasta sayısı nispeten kısıtlıdır ve tüm işlemler deneyimli bir endoskopist tarafından endoskopi ve sedasyon açısından optimum koşullarda yapılmıştır. Hastaların sedasyon düzeyleri az sayıdaki bazı araştırmacilar gibi bispektral indeksle (BİS) takip edilmemiştir (76). Yapılan işlemlerin tümü tanısal olup ciddi ağrı oluşturacak invaziv ek girişim uygulanmamıştır. Ayrıca hasta grubu ASA I-II olup ASA III ve üzeri hastalar ve ciddi komorbiditesi olanlar çalışma dışı bırakılmıştır. Bu tablo tanısal ve terapötik kolonoskopi planlanan hastaların genel profiline çok da fazla uygunluk göstermemektedir. Ek olarak etik nedenlerle sadece propofolun uygulandığ bir kontrol grubu da yoktur.

Sonuç olarak çalışmamız sonrasında tanısal endoskopi hastalarında, hasta ve hekim memnuniyetinin üst düzeyde olması, opioid kullanımı istenmeyen hastalarda ketaminin iyi bir alternatif olduğunu düşündürmektedir. Ancak diğer bazı çalışmalarla karşılaştırdığımızda daha düşük doz ketamin kullanmamıza karşın sedasyonun derinleşme eğiliminde olması, uyanma döneminde oranı yüksek olmasa da bazı istenmeyen yan etkilerin yaşanması ve derlenme periyodunun uzun sürmesi bize ketamin dozunu daha da azaltmanın mümkün olabileceğini, 3:1 yerine 10:1 $(12,77)$ hatta 20:1 (78) gibi seçeneklerin de irdelenmesi gerektiğini hatırlatmaktadır. Böylece sedasyonun derinleşmesini, derlenme süresinin uzamasını engellemek, hoş olmayan rüyalar vb. psikomimetik yan etkileri azaltmak ve ilaçtan kaynaklanabilecek yakınmaları minimalize etmek mümkün olabilir. Ancak düşen ketamin dozunun propofolun respiratuvar sisteme olan negatif etkilerini antagonize edemiyebileceğini ve respiratuvar komplikasyonların görülebileceği hatırda tutulmalıdır.

Yine de sedasyon uygulamasinda ideal bir ajan veya bileşimin var olmadığı, kullanılacak ajan/ajanların ve sedasyon hedefinin işlemin karakteri (işlemin süresi, ağrı oluşturma potansiyeli), hastanın kişisel özellikleri (yaş, komorbidite, anksiyete durumu), hastanın tercihleri ve işlem sırasında kooperasyon gerekliliği göz önünde bulundurularak hastanın ve yapılacak işlemin özelliklerine göre farklı ilaçlar veya bunların kombinasyonlarının seçilmesi gerektiği, sedasyon uygulaması yapan hekimlerin kullandı̆̆ tüm ilaçları yakından tanıması ve komplikasyonlarla baş edebilecek bilgi, beceri ve ekipmana sahip olması gerektiği unutulmamalıdır. 
Received Date/Geliş Tarihi: 20.06.2020

Accepted Date/Kabul Tarihi: 29.06.2020

\section{REFERANSLAR}

1. Wolf AMD, Fontham ETH, Church TR, Flowers CR, Guerra CE, LaMonte SJ, et al. Colorectal cancer screening for average-risk adults: 2018 guideline update from the American Cancer Society. CA Cancer J Clin. 2018 Jul;68(4):250-281.

2. Gerbershagen HJ, Aduckathil S, van Wijck AJ, Peelen LM, Kalkman CJ, Meissner W. Pain intensity on the first day after surgery: a prospective cohort study comparing 179 surgical procedures. Anesthesiology 2013;118:934-44

3. Kilgert B, Rybizki L, Grottke M, Neurath MF, Neumann H. Prospective long-term assessment of sedation-related adverse events and patient satisfaction for upper endoscopy and colonoscopy. Digestion. 2014;90(1):42-8.

4. Eberl S, Monteiro de Olivera N, Preckel B, Streitberger K, Fockens P, Hollmann MW. A randomised controlled trial: can acupuncture reduce drug requirement during analgosedation with propofol and alfentanil for colonoscopy? A study protocol. BMC Complement Altern Med. 2015 Nov 16;15:406.

5. Zhang F, Sun HR, Zheng ZB, Liao R, Liu J. Dexmedetomidine versus Midazolam for sedation during endoscopy: A meta-analysis. Exp Ther Med. 2016 Jun;11(6):25192524.

6. Fanti L, Testoni PA. Sedation and analgesia in gastrointestinal endoscopy: what's new? World J Gastroenterol. 2010 May 28;16(20):2451-7.

7. Frazee BW1, Park RS, Lowery D, Baire M. Propofol for deep procedural sedation in the ED. Am J Emerg Med. 2005 Mar;23(2):190-5.

8. Hug CC Jr, McLeskey CH, Nahrwold ML, Roizen MF, Stanley TH, Thisted RA, Walawander CA, White PF, Apfelbaum JL, Grasela TH, et al. Hemodynamic effects of Propofol: data from over 25,000 patients. Anesth Analg. 1993 Oct;77(4 Suppl):S21-9.

9. Wang F1, Shen SR, Xiao DH, Xu CX, Tang WL. Sedation, analgesia, and cardiorespiratory function in colonoscopy using Midazolam combined with fentanyl or Propofol. Int J Colorectal Dis. 2011 Jun;26(6):703-8.

10. Reves JG, Glass PSA, Lubarsky DA, McEvoy MD, Martinez-Ruiz R. Intravenous anesthetics. In: Miller RD, editor. Miller's Anesthesia. 7th ed. Philadelphia: Churchill Livingstone/Elsevier; 2010. p. 719-68.

11. Cohen SP1, Liao W, Gupta A, Plunkett A. Ketamine in pain management. Adv Psychosom Med. 2011;30:139-61.

12. Badrinath S, Avramov MN, Shadrick M, Witt TR, Ivankovich AD. The use of a Ketamine-Propofol combination during monitored anesthesia care. Anesth Analg. 2000 Apr;90(4):858-62.

13. Bektaş H, Balık E, Bilsel Y, et al. Comparison of sodium phosphate, polyethylene glycol, and senna solutions in bowel preparation: A prospective, randomizedcontrolled clinical study. Digestive Endoscopy 2005;17:290-96.

14. DeLoach LJ, Higgins MS, Caplan AB, Stiff JL. The visual analog scale in the immediate postoperative period: intrasubject variability and correlation with a numeric scale. Anest Analg 1998;86:102-6.

15. Trissel LA, Gilbert DL, Martinez JF. Compatibility of Propofol injectable emulsion with selected drugs during simulated Y-site administration. Am J Health Syst
Pharm. 1997 Jun 1;54(11):1287-92.

16. Hsieh YH, Chou AL, Lai YY, Chen BS, Sia SL, Chen IC, Chang YL, Lin HJ. Propofol alone versus Propofol in combination with meperidine for sedation during colonoscopy. J Clin Gastroenterol. 2009 Sep;43(8):753-7.

17. American Society of Anesthesiologists Task Force on Sedation and Analgesia by Non-Anesthesiologists. Practice guidelines for sedation and analgesia by non-anesthesiologists. Anesthesiology. 2002 Apr;96(4):1004-17.

18. Ramsay MA, Savege TM, Simpson BR, Goodwin R. Controlled Sedation with Alphaxalone-Alphadolone British MedicalJournal, 1974, 2, 656-659.

19. Chernik DA, Gillings D, Laine H, Hendler J, Silver JM, Davidson AB, Schwam EM, Siegel JL. Validity and reliability of the Observer's Assessment of Alertness/Sedation Scale: study with intravenous Midazolam. J Clin Psychopharmacol. 1990 Aug;10(4):244-51.

20. Aldrete JA. The post-anesthesia recovery score revisited. J Clin Anesth. 1995 Feb;7(1):89-91.

21. Torre LA1, Bray F, Siegel RL, Ferlay J, Lortet-Tieulent J, Jemal A. Global cancer statistics, 2012. CA Cancer J Clin. 2015 Mar;65(2):87-108.

22. Wang D, Chen C, Chen J, Xu Y, Wang L, Zhu Z, et all. The use of Propofol as a sedative agent in gastrointestinal endoscopy: a meta-analysis. PLoS One. 2013;8(1):e53311.

23. Türk Anesteziyoloji ve Reanimasyon Derneği (TARD9 Anestezi Uygulama Kılavuzları: Ameliyathane Dışı Anestezi Uygulamaları. Aralık 2015; s 11

24. Moon SH. Sedation regimens for gastrointestinal endoscopy. Clin Endosc. 2014 Mar;47(2):135-40.

25. Childers RE, Williams JL, Sonnenberg A. Practice patterns of sedation for colonoscopy. Gastrointest Endosc. 2015 Sep;82(3):503-11.

26. Khajavi M, Emami A, Etezadi F, Safari S, Sharifi A, Shariat Moharari R. Conscious Sedation and Analgesia in Colonoscopy: Ketamine/Propofol Combination has Superior Patient Satisfaction Versus Fentanyl/Propofol. Anesth Pain Med. 2013 Summer;3(1):208-13.

27. Duran FY, Özkalkanlı MY, Cengiz F. Gastrointestinal endoskopi uygulamalarnnda sedasyon uygulama farklllklarl: Anestezistler ve anestezist olmayanlar. Anestezi Dergisi 2014;22(1):43-45

28. Shin S, Oh TG, Chung MJ, Park JY, Park SW, Chung JB, et al. Conventional versus Analgesia-Oriented Combination Sedation on Recovery Profiles and Satisfaction after ERCP: A Randomized Trial. PLoS One. 2015 Sep 24;10(9):e0138422.

29. Gan TJ, Glass PS, Howell ST, Canada AT, Grant AP, Ginsberg B. Determination of plasma concentrations of propofol associated with $50 \%$ reduction in postoperative nausea. Anesthesiology. 1997 Oct; 87(4):779-84.

30. Laosuwan S, Pongruekdee S, Thaharavanich R. Comparison of effective-site target controlled infusion and manually controlled infusion of propofol for sedation during spinal anesthesia. J Med Assoc Thai. 2011 Aug;94(8):965-71..

31. Holas A, Krafft P, Marcovic M, Et al. Remifentanil, Propofol or both for concious sedation during eye surgery under regional anesthesia. Eur J Anaesth 1999;16:741-48 
32. Haytural C, Aydınlı B, Demir B, Bozkurt E, Parlak E, Dişibeyaz S, et al. Comparison of Propofol, Propofol-Remifentanil, and Propofol-Fentanyl Administrations with Each Other Used for the Sedation of Patients to Undergo ERCP. Biomed Res Int. 2015;2015:465465.

33. Yamanaka T, Sadikot RT. Opioid effect on lungs. Respirology. 2013 Feb;18(2):25562.

34. Kim DJ, Bengali R, Anderson TA. Opioid-free anesthesia using continuous dexmedeto-midine and lidocaine infusions in spine surgery. Korean J Anesthesiol. 2017 Dec;70(6):652-653.

35. Armenian P, Vo KT, Barr-Walker J, Lynch KL. Fentanyl, fentanyl analogs and novel synthetic opioids: A comprehensive review. Neuropharmacology. 2018 May 15;134(Pt A):121-132.

36. Triantafillidis JK, Merikas E, Nikolakis D, Papalois AE. Sedation in gastrointestinal endoscopy: current issues. World J Gastroenterol. 2013 Jan 28;19(4):463-81. Review

37. A de Castro. Opioid free Anaesthesia University of Kwazulu-Natal 2016 (3) No. 05 http://anaesthetics.ukzn.ac.za/Libraries/ICU_1/FMM_No5_04-03-2016_ OFA_A_de_Castro.sflb.ashx

38. Çoruh B, Tonelli MR, Park DR. Fentanyl-induced chest wall rigidity. Chest. 2013 Apr;143(4):1145-1146. doi: 10.1378/chest.12-2131.

39. Steven B. Rosenbaum, Jorge L. Palacios. Ketamine. StatPearls. Treasure Island (FL): StatPearls Publishing; 2018 Jan-.

40. P eltoniemi MA, Hagelberg NM, Olkkola KT, Saari TI. Ketamine: A Review of Clinical Pharmacokinetics and Pharmacodynamics in Anesthesia and Pain Therapy. Clin Pharmacokinet. 2016 Sep;55(9):1059-77.

41. Baykal Tutal Z, Gulec H, Dereli N, Babayigit M, Kurtay A, Inceoz H, Horasanl E. Propofol-Ketamine combination: a choice with less complications and better hemodynamic stability compared to Propofol? On a prospective study in a group of colonoscopy patients. Ir J Med Sci. 2016 Aug;185(3):699-704.

42. Jalili M, Bahreini M, Doosti-Irani A, Masoomi R, Arbab M, Mirfazaelian H. Ketamine-Propofol combination (Ketofol) vs Propofol for procedural sedation and analgesia: systematic review and meta-analysis. Am J Emerg Med. 2016 Mar;34(3):558-69.

43. Tezcan AH, Önek DH, Yavuz N, Ünal H, Postacı AN, Terzi HÖ, et al. The comparison of Propofol and Ketofol side effects during sedation with spinal anesthesia. Kafkas J Med Sci 2017;7(3):236-242

44. Andolfatto G, Abu-Laban RB, Zed PJ, Staniforth SM, Stackhouse S, Moadebi S, Willman E. Ketamine-Propofol combination (Ketofol) versus Propofol alone for emergency department procedural sedation and analgesia: a randomized double-blind trial. Ann Emerg Med. 2012 Jun;59(6):504-12.e1-2.

45. Arora S. Combining Ketamine and Propofol ("Ketofol") for emergency department procedural sedation and analgesia: a review. West J Emerg Med. 2008 Jan;9(1):20-3.

46. Abdellatif AA. Ketofol for outpatient transrectal ultrasound guided prostate biopsy. Ain Shams J Anesthesiol 2012;5:11-22.

47. Aydogan H, Aydogan T, Koglu A, et al. Propofol-Ketamine combination has shorter recovery times with similar hemodynamics compared to Propofol alone in upper gastrointestinal endo-scopy in adults. A randomized trial. Acta Med Mediterr 2013;29:259-64.

48. Tandon M, Pandey VK, Dubey GK, Pandey CK, Wadhwa N. Addition of sub-anaesthetic dose of Ketamine reduces gag reflex during Propofol based sedation for upper gastrointestinal endoscopy: A prospective randomised double-blind study. Indian J Anaesth. 2014 Jul;58(4):436-41.

49. Fabbri LP, Nucera M, Marsili M, et al. Ketamine, Propofol and low dose remifentanil versus Propofol and remifentanil for ERCP outside the operating room: is Ketamine not only a "rescue drug"? Med Sci Monit 2012;18(9):CR575-80.

50. Tang YY, Lin XM,vora Huang W, et al. Addition of low-dose Ketamine to Propofolfentanyl sedation for gynecologic diagnostic laparoscopy: randomized controlled trial. J Minim Invasive Gynecol 2010;17(3):325-30.

51. Miner JR, Moore JC, Austad EJ, et al. Randomized, double-blinded, clinical trial of Propofol, 1: 1 Propofol/Ketamine, and 4: 1 Propofol/Ketamine for deep procedural sedation in the emergency department. Ann Emerg Med 2015;65(5):47988

52. Yuce HH, Kucuk A, Altay N, et al. Propofol-Ketamine combination has favorable impact on orientation times and pain scores compared to Propofol in dilatation and curettage. A randomized trial. Acta Medica Mediterr, 2013;29:539

53. Mortero RF, Clark LD, Tolan MM, Metz RJ, Tsueda K, Sheppard RA. The effects of small-dose Ketamine on Propofol sedation: respiration, postoperative mood, perception, cognition, and pain. Anesth Analg. 2001 Jun;92(6):1465-9.

54. Cillo Jr JE. Analysis of Propofol and low-dose Ketamine admixtures for adult outpatientdentoalveolar surgery: a prospective, randomized, positive-controlled clinical trial. J Oral Maxillofac Surg 2012;70(3):537-46

55. Lemoel F, Contenti J, Giolito D, Boiffier M, Rapp J, Istria J, et al. Adverse Events With Ketamine Versus Ketofol for Procedural Sedation on Adults: A Double-blind, Randomized Controlled Trial. Acad Emerg Med. 2017 Dec;24(12):14411449 .

56. Başaranoğlu G, Esen A, Bakan M, Topuz U, İdin K, Umutoğlu T. Ketalar Propofol karışımının sedasyon ve analjezide kullanımı. Med Bull Haseki 2015; 53: 41-46

57. Phillips W, Anderson A, Rosengreen M, et al. Propofol versus Propofol/Ketamine for brief painful procedures in the emergency department: clinical and bispectral index scale comparison. J Pain Palliat Care Pharmacother 2010;24(4):349-55.

58. Türk HŞ, Aydoğmuş M, Ünsal O, Işıl CT, Citgez B, Oba S, Açık ME. Ketamine versus alfentanil combined for sedation in colonoscopy procedures: Arandomized prospective study. Turk J Gastroenterol 2014;25:644-9

59. Arikan M, Aslan B, Arikan O, But A, Horasanli E. Comparison of Propofol-remifentanil and Propofol-Ketamine combination for dilatation and currettage: a randomized double blind prospective trial. Eur Rev Med Pharmacol Sci. 2015 Sep;19(18):3522-7.

60. Hui TW, Short TG, Hong W, Suen T, Gin T, Plummer J. Additive interactions between Propofol and Ketamine when used for anesthesia induction in female patients. Anesthesiology. 1995 Mar;82(3):641-8.

61. Kinoshita T, Suzuki M, Shimada Y, et al. Effect of low-dose Ketamine on redist- 
ribution hypothermia during spinal anesthesia sedated by Propofol. J Nippon Med Sch 2004;71(2):92-8

62. Olson AN, Rao WR, Marienau ME, Smischney NJ. Period Prevalence of Ketamine-Propofol Admixture "Ketofol" in the Operating Room among Anesthesia Providers at an Academic Medical Center. Med Sci Monit. 2015 Jun 16;21:1737-44.

63. Nengroo S, Lone AQ, Naqash I. Circulatory responses to Propofol-Ketamine combination EJOURNAL 2011;6(2).

64. Angsuwatcharakon P, Rerknimitr R, Ridtitid W, Kongkam P, Poonyathawon S, Ponauthai Y, et al. Cocktail sedation containing Propofol versus conventional sedation for ERCP: a prospective, randomized controlled study. BMC Anesthesiol. 2012 Aug 9;12:20.

65. De Oliveira Jr GS, Fitzgerald PC, Hansen N, et al. The effect of Ketamine on hypoventilation during deep sedation with Midazolam and Propofol: a randomised, double-blind, placebo-controlled trial. Eur J Anaesthesiol 2014;31(12):654-62.

66. Willman EV, Andolfatto G. A prospective evaluation of "Ketofol" (Ketamine/Propofol combination) for procedural sedation and analgesia in the emergency department. Ann Emerg Med 2007;49(1):23-30.

67. Andolfatto G, Willman E. A prospective case series of single-syringe KetaminePropofol (Ketofol) for emergency department procedural sedation and analgesia in adults. Acad Emerg Med 2011;18(3):237-45.

68. Green SM, Andolfatto G. Managing Propofol-induced hypoventilation. Ann Emerg Med 2015;65(1):57-60.

69. Sahoo AK, Mandal I, Kalpana M. Clinical evaluation of effects of intravenous in duction agents: Propofol, Ketamine and etomidate on blood sugar level. JMSCR 2018;06(01):32364-69
Sharif SI, Abouazra HA. Effect of intravenous Ketamine administration on blood glucose levels in conscious rabbits Am J Pharmacol Toxicol. 2009;4(2):3845.

71. Huayong Chen, $\mathrm{Li} \mathrm{Li,} \mathrm{Hui} \mathrm{Xia.} \mathrm{Diabetes} \mathrm{alters} \mathrm{the} \mathrm{blood} \mathrm{glucose} \mathrm{response} \mathrm{to}$ Ketamine in streptozotocin-diabetic rats. Int J Clin Exp Med 2015;8(7):1134711351

72. Strayer RJ, Nelson LS. Adverse events associated with Ketamine for procedural sedation in adults. Am J Emerg Med. 2008 Nov;26(9):985-1028.

73. Nagata A, Nakao S, Miyamoto E, Inada T, Tooyama I, Kimura H, Shingu K. Propofol inhibits Ketamine-induced c-fos expression in the rat posterior cingulate cortex. Anesth Analg. 1998 Dec;87(6):1416-20.

74. Nakao S, Nagata A, Miyamoto E, Masuzawa M, Murayama T, Shingu K. Inhibitory effect of Propofol on Ketamine-induced c-Fos expression in the rat posterior cingulate and retrosplenial cortices is mediated by GABAA receptor activation. Acta Anaesthesiol Scand. 2003 Mar;47(3):284-90.

75. Fabbri LP, Nucera M, Marsili M, Al Malyan M, Becchi C. Ketamine, Propofol and low dose remifentanil versus Propofol and remifentanil for ERCP outside the operating room: is Ketamine not only a "rescue drug"? Med Sci Monit. 2012 Sep;18(9):CR575-80.

76. Akarsu Ayazoğlu T, Polat E, Bolat C, Yasar NF, Duman U, Akbulut S, Yol S. Comparison of propofol-based sedation regimens administered during colonoscopy. Rev Med Chil. 2013 Apr;141(4):477-85.

77. Frizelle HP,Duranteau J, Samii K. A comparison of Propofol with a Propofol-Ketamine combination for sedation during spinal anesthesia. Anesth Analg 1997;84(6):1318-22.

78. Lee KC, Shi H, Lee BC. Ketofol for monitored anesthesia care in shoulder arthroscopy and labral repair: a case report. J Pain Res. 2016 Jun 17;9:417-20. 